\title{
PLANNING OPTIMIZATION PLANNING IRIGATION AREA OF SOLOK SUMATERA WEST REGENCY
}

\author{
Acep Hidayat, \\ Faculty of Engineering, University MercuBuana Jakarta, Indonesia \\ acep hidayat@mercubuana.ac.id \\ Deri Ferdina \\ Faculty of Engineering, University MercuBuana Jakarta, Indonesia
}

\begin{abstract}
ABSTRACK
Solok Regency irrigation network planning which has an area of irrigation land of 3738 ha. The main canals are spread in several areas, namely 43 Irrigation Channels, 17 Dams, 7 Reservoirs and 2 lakes which are still functioning in Solok Regency. The poverty rate in Solok Regency is still quite high, reaching $27,487 \%$. The data includes secondary data on 10-year rainfall data from KayuAro, Bayur Maritime Bay Methodology, Padang Panjang Geophysics and 10-year climatology from KayuAro Climatology Station. The calculation method used is the intensity of theissen rainfall method, Evapotranspiration of the modified Penman method, the reliable discharge of the DR.FJ Mock method, the cropping pattern, and the need for irrigation water. The most efficient and optimal planting pattern obtained is PADI-PADI-CORN with large irrigation water requirements in tertiary plots (NFR tertiary plots) ranging from 0 $1,546 \mathrm{Itr} / \mathrm{sec} / \mathrm{ha}$ with a maximum of 1,546 Itr / sec / ha in September II, whereas Irrigation water demand in the intake (DR intake) ranges from 0 to 2,378 Itr $\mathrm{sec} / \mathrm{ha}$ with a maximum of 2,378 Itr / sec / ha in September II.The mainstay discharge available in the Pauh Tinggi Irrigation Network Planning is very abundant with the mainstay discharge (Q80) for irrigation, the maximum mainstay discharge (Q80) occurs in April I with $10.482 \mathrm{ltr} / \mathrm{sec} / \mathrm{ha}$ and minimum in December II with 3,930 Itr / sec / ha. Based on the mainstay discharge results above it can be stated that the water balance / water balance between the mainstay discharge Q80 and the need for irrigation water experienced a large surplus..
\end{abstract}

Keywords: Planting pattern, SolokRegency irrigation network, reliable discharge.

\section{INTRODUCTION}

Water is a natural resource that is very important for the survival of all living things. Water is also very necessary for industrial activities, fisheries, agriculture and other businesses. In the use of water often occurs inadvertently in the use and utilization so that efforts are needed to maintain the balance between the availability and demand of water through development, preservation, repair and protection [1]

Indonesia is a region with a large portion of agricultural area, therefore most of the population looks for a living as farmers. One of them is Solok Regency which has an area of 3738 ha with an area of 3106 ha is agricultural land and 234.39 ha is non-agricultural land [2]. With this area, a good irrigation system is needed. The use of irrigation in Solok Regency is not balanced with the availability of water available. With the problem of the difference between water availability and water needs, it is necessary to do the right planting pattern in the Irrigation District of Solok Regency. Aiming to take advantage of excess water in the rainy season to supply water shortages in the dry season. Through Alternative Planting Patterns (PTT) can be obtained maximum yield of crops. By maximizing the existing agricultural areas indirectly the economy in the irrigation area will also increase. Besides being able to optimize the yield of PTT crops, it can also increase farmers' income and the economy in Solok Regency. 
Solok Regency area $39.66 \%$ of the majority of the population is eyed as farmers with an area of 3106 ha of agricultural land and 234.39 ha of non-agricultural land. The poverty rate in Solok Regency is still quite high, reaching 27,487 [3]Thus, to improve the economy of the people of Solok Regency, one of the efforts that can be done is to increase business in the agricultural sector by planning optimization of farming patterns in the agricultural area.

\section{Theoretical Basis}

\section{Definition of Irrigation}

Irrigation is activities related to the efforts to get rice water, fields, plantations and other agricultural businesses, swamps, fisheries. The main business involves the creation of facilities and infrastructure to distribute water to the fields regularly and remove excess water that is no longer needed by agricultural businesses.

\section{Irrigation Network}

Based on how water flow measurements are regulated and facilities are complete, irrigation networks can be divided into three levels, see Table 2.1:

1. Simple Irrigation Networks

2. Semiteknis Irrigation Network

3. Technical Irrigation Network

\begin{tabular}{|c|c|c|c|c|}
\hline & \multicolumn{3}{|c|}{ Klasifikasi jaringan irigasi } \\
\hline & & Teknis & Semiteknis & Sederhana \\
\hline 1 & $\begin{array}{l}\text { Bangunan } \\
\text { Utama }\end{array}$ & $\begin{array}{l}\text { Bangunan } \\
\text { permanen }\end{array}$ & $\begin{array}{l}\text { Bangunan } \\
\text { permanen atau } \\
\text { semi permanen }\end{array}$ & $\begin{array}{l}\text { Bangunan } \\
\text { sementara }\end{array}$ \\
\hline 2 & $\begin{array}{l}\text { Kemampuan } \\
\text { bangunan } \\
\text { dalam } \\
\text { mengukur } \\
\text { dan mengatur } \\
\text { debit }\end{array}$ & Baik & Sedang & Jelek \\
\hline 3 & $\begin{array}{l}\text { Jaringan } \\
\text { saluran }\end{array}$ & $\begin{array}{l}\text { Saluran irigasi } \\
\text { dan pembuang } \\
\text { terpisah }\end{array}$ & $\begin{array}{l}\text { Saluran irigasi } \\
\text { dan pembuang } \\
\text { tidak } \\
\text { sepenuhnya } \\
\text { terpisah }\end{array}$ & $\begin{array}{l}\text { Saluran irigasi } \\
\text { dan pembuang } \\
\text { jadi satu }\end{array}$ \\
\hline 4 & Petak tersier & $\begin{array}{l}\text { Dikembangkan } \\
\text { sepenuhnya }\end{array}$ & $\begin{array}{l}\text { Belum } \\
\text { dikembangkan } \\
\text { atau densitas } \\
\text { bangunan } \\
\text { tersier jarang }\end{array}$ & $\begin{array}{l}\text { Belum ada } \\
\text { jaringan } \\
\text { terpisah yang } \\
\text { dikembangkan }\end{array}$ \\
\hline 5 & $\begin{array}{l}\text { Efisiensi } \\
\text { secara } \\
\text { keseluruhan }\end{array}$ & $\begin{array}{l}\text { Tinggi } \\
50-60 \% \\
\text { (Ancar-ancar) }\end{array}$ & $\begin{array}{l}\text { Sedang } \\
40-50 \% \\
\text { (Ancar-ancar) }\end{array}$ & $\begin{array}{l}\text { Kurang } \\
<40 \% \\
\text { (Ancar-ancar }\end{array}$ \\
\hline 6 & Ukuran & $\begin{array}{l}\text { Tak ada } \\
\text { batasan }\end{array}$ & $\begin{array}{l}\text { Sampai } 2.000 \\
\text { ha }\end{array}$ & $\begin{array}{l}\text { Tak lebih dari } \\
500 \text { ha }\end{array}$ \\
\hline 7 & $\begin{array}{l}\text { Jalan Usaha } \\
\text { Tani }\end{array}$ & $\begin{array}{l}\text { Ada ke seluruh } \\
\text { areal }\end{array}$ & $\begin{array}{l}\text { Hanya sebagian } \\
\text { areal }\end{array}$ & $\begin{array}{l}\text { Cenderung } \\
\text { tidak ada }\end{array}$ \\
\hline 8 & Kondisi O \& P & $\begin{array}{l}\text { - Ada instansi } \\
\text { yang } \\
\text { menangani } \\
\text { - Dilaksanakan } \\
\text { teratur }\end{array}$ & Belum teratur & $\begin{array}{l}\text { Tidak ada } \\
\text { O \& P }\end{array}$ \\
\hline
\end{tabular}

Irrigation Network Classification Table

(Sumber:KP-01 Standar Perencanaan Irigasi)

Simple Network, In simple irrigation, see figure 2.1 Water distribution is not measured or regulated, more water will flow into the sewer. The water user farmers are incorporated in the same irrigation network group, so there is no need for government involvement in this kind of irrigation network organization. Water supplies are usually abundant with slopes ranging 
from moderate to steep. Therefore, there is almost no need for difficult techniques for the water distribution system.

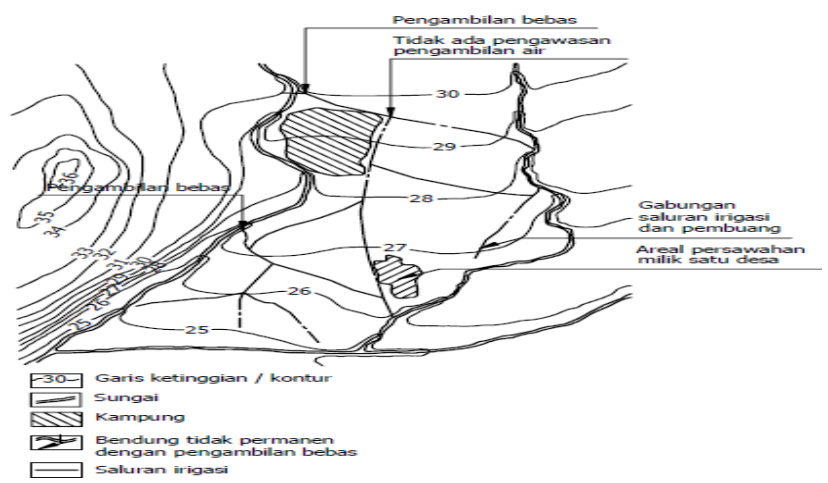

Figure 2.1 Simple Irrigation Networks

(Sumber:KP-01 Standar Perencanaan Irigasi)

Semiteknis Irrigation, In many ways, the only difference between a simple irrigation network and a semitek technical network is that the semitek technical network is located on a river complete with a retrieval building and measuring structure downstream. Some permanent buildings might also be built on a network of canals. Water distribution systems are usually similar to simple networks (see Figure 2.2). It is possible that retrieval is used to serve / irrigate a wider area than the service area on a simple network. Therefore the costs are borne by more service areas. The organization will be more complicated if the permanent building takes the form of taking buildings from the river, because it requires more involvement from the government, in this case the Department of Public Works.

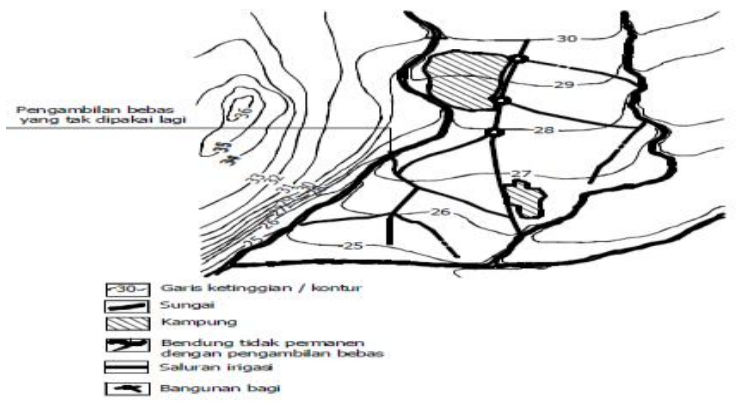

Figure 2.2 Semiteknis Irrigation Network

(Sumber:KP-01 Standar Perencanaan Irigasi)

Technical Irrigation, One of the principles in technical network planning is the separation between irrigation networks and waster / pematus networks. This means that both the irrigation channel and the waster still work in accordance with their respective functions, from the base to the tip. Irrigation channels drain irrigation water into the fields and the drainage channel flows more water from the fields to the natural drainage channel which will then be forwarded to the sea (see Figure 2.3). The advantages that can be obtained from such a combined network are the more economical use of water and lower channel construction costs, because the carrier channel can be made shorter with a smaller capacity. 
The disadvantages include that this kind of network is more difficult to regulate and operate frequently, floods more quickly, and shows uneven water distribution. Certain buildings in the network will have properties such as weirs and are relatively expensive.

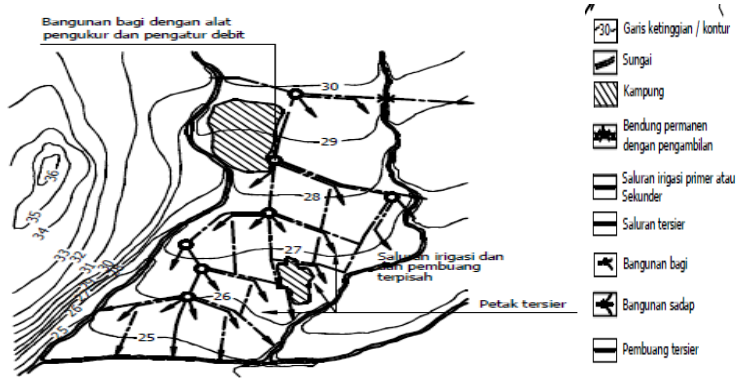

Figure 2.2 Technical Irrigation Networks (Sumber:KP-01 Standar Perencanaan Irigasi)

\section{Evapotranspiration}

Analyzing climatology data in the form of data on air temperature, humidity, duration of solar radiation, and wind speed at the climatology station closest to the Irrigation area to look for potential evapotranspiration

The method used here is the Penman Modification method. To calculate ETO using the Penman modification method, the formulas used are:

$$
\begin{array}{ll}
\mathrm{e}_{\mathrm{s}} & =611 \exp \left(\frac{17,27 T}{237,3+T}\right) \\
\mathrm{e}_{\mathrm{d}} \quad & =\mathrm{e}_{\mathrm{s}} \mathrm{r} \\
\mathrm{E}=\mathrm{B}\left(\mathrm{e}_{\mathrm{s}}-\mathrm{e}_{\mathrm{d}}\right) & \\
\mathrm{B}=\frac{0,102 u_{2}}{\left(\ln \left(\frac{z_{2}}{z_{0}}\right)\right)^{2}} & \\
\mathrm{~L}_{\mathrm{n}} \quad= & \sigma \mathrm{T}^{4}(0,56-0,092 \sqrt{\mathrm{ed}})\left(0,1+0,9 \frac{\mathrm{n}}{\mathrm{N}}\right) \\
\mathrm{S}_{\mathrm{t}} \quad=\mathrm{S}_{0}(\mathrm{a}+(\mathrm{b} \times \mathrm{n} / 12,1)) \\
\mathrm{S}_{\mathrm{n}} \quad=\mathrm{S}_{\mathrm{t}}(1-\alpha) \\
\mathrm{R}_{\mathrm{n}} \quad=\mathrm{S}_{\mathrm{n}}-\mathrm{L}_{\mathrm{n}} \\
\mathrm{I}_{\mathrm{v}}=597,3-0,56 \mathrm{~T} \\
\mathrm{E}_{\mathrm{n}} \quad=\frac{\mathrm{Rn}}{\rho \mathrm{wlv}} \\
\mathrm{ET}_{0} \quad=\frac{\beta \mathrm{En}+\mathrm{E}}{\beta+1}
\end{array}
$$

Information:

$A=$ reflection coefficient (albedo)

$\mathrm{B}=$ temperature function

$\Sigma=$ Stevan-Boltzman constant (1.17. 10-7 cal / cm2 / K4 / day)

$\mathrm{Pw} \quad=$ density of water $(1 \mathrm{gr} / \mathrm{cm} 3)$

ed $\quad=$ water vapor pressure at elevation $2 \mathrm{~m}$ on the surface $(\mathrm{mmHg})$

ice $\quad=$ saturated water vapor pressure

$\mathrm{E}=$ Evaporation ( $\mathrm{mm} /$ day)

En = depth of evaporation ( $\mathrm{cm} /$ day)

ETO = potential Evapotranspiration $(\mathrm{mm} /$ day $)$

Iv $=$ latent heat for evaporation (cal / gram)

Ln = Long-wave radiation emitted earth (cal / $\mathrm{cm} 2 /$ day)

$\mathrm{n} / \mathrm{N} \quad=$ duration of daily sun exposure (\%)

$\mathrm{N}=$ Maximum exposure duration of hours=12.1 hours (Triadmojo, 2014: 62)

$r=$ relative humidity $(\%)$

$\mathrm{Rn} \quad=$ Net radiation

So = Shortwave radiation on the outer edge atmosphere (cal / $\mathrm{cm} 2 /$ day)

$\mathrm{Sn} \quad=$ Net absorbed solar radiation Earth surface 
$\mathrm{T}=$ absolute temperature at elevation $2 \mathrm{~m}$ above surface $(0 \mathrm{~K})(0 \mathrm{C})$

u2 $=$ Wind speed at a distance of $2 \mathrm{~m}$ above surface $(\mathrm{m} / \mathrm{sec})$

$\mathrm{z0}=$ = high roughness given by table 2.6

z2 $=2$ meters above sea level

Table 2.2. Values $a$ and $b$

\begin{tabular}{ccc}
\hline Area & $\mathrm{a}$ & $\mathrm{b}$ \\
\hline Cold and temperate & 0.18 & 0.55 \\
Dry tropics & 0.25 & 0.45 \\
Wet tropics & 0.29 & 0.42 \\
\hline \multicolumn{2}{c}{ (Sumber: Triatmodjo, 2014) }
\end{tabular}

Table 2.3. $\beta$ Value Based on Temperature

\begin{tabular}{cc}
\hline $\mathbf{T}\left({ }^{\circ} \mathbf{C}\right)$ & $\boldsymbol{\beta}=\boldsymbol{\Delta} / \mathbf{Y}$ \\
\hline 0 & 0,68 \\
5 & 0,93 \\
10 & 1,25 \\
15 & 1,66 \\
20 & 2,19 \\
25 & 2,86 \\
30 & 3,69 \\
35 & 4,73 \\
\hline \multicolumn{2}{c}{ (Sumber: Triatmodjo, 2014) }
\end{tabular}

Table 2.4. $\alpha$ value (albedo)

\begin{tabular}{cccc}
\hline Type of face & \multicolumn{2}{c}{ Albedo $(\boldsymbol{\alpha})$} \\
\hline Open water & 0,05 & - & 0,15 \\
Rock & $0,12-$ & 0,15 \\
Sand & $0,10-$ & 0,20 \\
Dry soil & 0,14 & 0,09 \\
Wet ground & $0,08-$ & 0,09 \\
Forest & $0,05-$ & 0,20 \\
Grass & $0,10-$ & 0,33 \\
Dry grass & $0,15-$ & 0,25 \\
Snow & 0,90 \\
Ice & $0,40-$ & 0,50 \\
Plant & 0,20 \\
\hline (Sumber: Triatmodjo, 2014)
\end{tabular}

Table 2.5. High roughness according to surface type (z0)

\begin{tabular}{cc}
\hline Type of face & High Roughness \\
\hline Ice, flat mud & 0.001 \\
Ice & $0.01-0.06$ \\
Grass $(<10) \mathrm{cm}$ & $0.1-2.0$ \\
Plants $(10-50) \mathrm{cm}$ & $2-5$ \\
Plants $(1-2) \mathrm{m}$ & 20 \\
Tree $(10-15) \mathrm{m}$ & $40-70$ \\
\hline \multicolumn{2}{c}{ (Sumber: Triatmodjo, 2014) }
\end{tabular}


Table 2.6. Shortwave Radiation on the Outer Edge of the Atmosphere

\begin{tabular}{|c|c|c|c|c|c|c|c|c|c|c|c|c|}
\hline I intang & Jan & Feb & Mar & Apr & Mei & Jun & Jul & Agu & Sep & Olat & Nov & Des \\
\hline $90^{\circ}$ LS & 0 & 0 & 40 & 470 & 900 & 1085 & 1010 & 670 & 170 & 0 & 0 & 0 \\
\hline$S 0^{\circ}$ LS & 0 & 0 & 125 & 480 & 890 & 1075 & 995 & 660 & 255 & 25 & 0 & 0 \\
\hline $70^{\circ} \mathrm{LS}$ & 0 & 70 & 275 & 565 & 855 & 1025 & 945 & 685 & 385 & 145 & 15 & 0 \\
\hline $60^{\circ} \mathrm{LS}$ & 90 & 215 & 425 & 670 & 890 & 1000 & 945 & 770 & 510 & 285 & 120 & 60 \\
\hline $50^{\circ}$ LS & 225 & 360 & 555 & 750 & 930 & 1010 & 970 & 830 & 640 & 435 & 265 & 190 \\
\hline $40^{\circ}$ LS & 380 & 505 & 675 & 845 & 965 & 1020 & 985 & 895 & 740 & 565 & 415 & 335 \\
\hline $30^{\circ} \mathrm{LS}$ & 520 & 630 & 775 & 895 & 975 & 1000 & 990 & 925 & 820 & 685 & 560 & 490 \\
\hline $20^{\circ}$ LS & 660 & 750 & 850 & 920 & 960 & 965 & 960 & 935 & 875 & 785 & 685 & 630 \\
\hline $10^{\circ} \mathrm{LS}$ & 780 & 840 & 900 & 925 & 915 & 900 & 905 & 915 & 905 & 865 & 800 & 760 \\
\hline $0^{2}$ & 885 & 915 & 925 & 900 & 850 & 820 & 830 & 870 & 905 & 910 & 890 & 875 \\
\hline $10^{\circ} \mathrm{LU}$ & 965 & 960 & 915 & 840 & 755 & 710 & 730 & 795 & 875 & 935 & 955 & 960 \\
\hline $20^{\circ} \mathrm{LU}$ & 1020 & 975 & 88 & 765 & 650 & 590 & 615 & 705 & 820 & 930 & 1000 & 1025 \\
\hline $30^{\circ} \mathrm{LU}$ & 1050 & 965 & 830 & 665 & 525 & 460 & 480 & 595 & 750 & 900 & 1020 & 1065 \\
\hline $40^{\circ} \mathrm{LU}$ & 1055 & 925 & 740 & 545 & 390 & 315 & 345 & 465 & 650 & 840 & 995 & 1080 \\
\hline $50^{\circ} \mathrm{LU}$ & 1035 & 865 & 640 & 415 & 250 & 180 & 205 & 325 & 525 & 760 & 975 & 1075 \\
\hline $60^{\circ} \mathrm{LU}$ & 1000 & 785 & 510 & 280 & 110 & 55 & 75 & 190 & 390 & 660 & 920 & 1060 \\
\hline $70^{\circ} \mathrm{LU}$ & 1000 & 695 & 375 & 130 & 10 & 0 & 0 & 55 & 250 & 550 & 885 & 1090 \\
\hline $80^{\circ} \mathrm{LU}$ & 1035 & 645 & 225 & 15 & 0 & 0 & 0 & 0 & 100 & 450 & 905 & 1140 \\
\hline $90^{\circ}$ LU & 1055 & 660 & 135 & 0 & 0 & 0 & 0 & 0 & 15 & 440 & 920 & 1160 \\
\hline
\end{tabular}

(Sumber: Triatmodjo, 2014)

\section{Rainfall Data Analysis}

Theissen method, weighted average, each rain station is determined by the area of influence based on the polygon formed (drawing the axis lines on the connecting lines between two adjacent rain stations). This method is obtained by making polygons that intersect perpendicular to the middle line connecting two rain stations. Thus each $\mathrm{Rn}$ measuring station will be located on a certain polygon An. By calculating the area ratio for each station of magnitude $=A n / A$, where $A$ is the area of the shelter area or the total area of the area sought for high rainfall. Average rainfall is obtained by summing each penakar that has an area of influence formed by drawing axis lines perpendicular to the connecting line between two penakar posts. [6]

The calculation method is as follows:

$$
\begin{aligned}
& d=\frac{A 1 \cdot d 1+A 2 \cdot d 2+A 3 \cdot d 3 \ldots . .+A n \cdot d n}{A}=\sum \frac{A i \cdot d i}{A} \\
& =\text { Area }(\mathrm{km} 2)
\end{aligned}
$$

\section{Mainstay Discharge}

Dependent flow (dependable flow) is the minimum flow of the river for a predetermined possibility that can be used for irrigation. The probability of being fulfilled is set at $80 \%$ (the possibility that the river discharge is lower than the mainstay discharge is $20 \%$ ) [7] 
The mainstay rainfall calculation is done by the formula:

$\mathrm{R} 80=\frac{\mathrm{n}}{5}+1$

Information:

$\mathrm{n} \quad=$ Rainfall observation period (year)

$\mathrm{R} 80=$ Mainstay rainfall of plants with the possibility of rain that is smaller than $\mathrm{R} 80$ has a probability of $20 \%$, while those greater or equal to R80 have a $80 \%$ chance of occurring.

\section{Rice Water Needs}

rrigation water demand is the amount of water volume needed to meet the needs of evapotranspiration, water loss, water requirements for plants by paying attention to the amount of water provided by nature through rain and the contribution of ground water. [1]

Calculation of irrigation water needs (NFR) can be done with the formula:

$$
\begin{aligned}
& \mathrm{NFR}=\mathrm{ETC}+\mathrm{Pd}+\mathrm{P}+\mathrm{WLR}-\mathrm{Re} \\
& \text { Information: } \\
& \text { NFR = Net Field Requirements in the fields ( } \mathrm{mm} / \text { day) } \\
& \text { ETC = Consumptive water requirements }(\mathrm{mm} / \text { day) } \\
& \mathrm{Pd} \quad=\text { Water requirements for land preparation including nursery }(\mathrm{mm} / \mathrm{day}) \\
& \mathrm{P}=\text { water loss due to percolation ( } \mathrm{mm} / \text { day) } \\
& \text { WLR = Replacement of a layer of standing water ( } \mathrm{mm} / \text { day) } \\
& \mathrm{Re} \quad=\text { effective rainfall }(\mathrm{mm} / \text { day) }
\end{aligned}
$$

\begin{tabular}{|c|c|c|c|c|c|c|}
\hline \multicolumn{2}{|c|}{ Umur tanaman } & \multicolumn{2}{|l|}{$\mathrm{RH}_{\min }<70 \%$} & \multicolumn{3}{|c|}{$\mathrm{RH}_{\min }<20 \%$} \\
\hline 12 bulan & 24 bulan & Tahap pertumbuhan & $\begin{array}{l}\text { gin kecil } \\
\text { pai sedang }\end{array}$ & $\begin{array}{l}\text { angin } \\
\text { kencang }\end{array}$ & $\begin{array}{l}\text { angin kecil } \\
\text { sampai sedang }\end{array}$ & $\begin{array}{l}\text { angin } \\
\text { kencang }\end{array}$ \\
\hline $0-1$ & $0-2,5$ & saat tanam sampai 0,25 rimbun *) & 55 & .6 & .4 & .45 \\
\hline $1-2$ & $2,5-3,5$ & $0,25-0,5$ rimbun & .8 & .85 & .75 & .8 \\
\hline $2-2,5$ & $3,5-4,5$ & $0,5-0,75$ rimbun & .9 & .95 & .95 & 1,0 \\
\hline $2,5-4$ & $4,5-6$ & 0,75 sampai rimbun & 1,0 & 1,1 & 1,1 & 1,2 \\
\hline $4-10$ & $6-17$ & penggunaan air puncak & 1,05 & 1,15 & 1,25 & 1,3 \\
\hline $10-11$ & $17-22$ & awal berbunga & .8 & .85 & .95 & 1,05 \\
\hline $11-12$ & $22-24$ & menjadi masak & .6 & .65 & .7 & .75 \\
\hline
\end{tabular}

\section{Crop Coefficient (Kc)}

\begin{tabular}{|c|c|c|c|c|}
\hline \multirow[b]{2}{*}{ Bulan } & \multicolumn{2}{|c|}{ Nedeco/Prosida } & \multicolumn{2}{|c|}{ FAO } \\
\hline & $\begin{array}{c}\text { Varietas }^{2} \\
\text { Biasa }\end{array}$ & $\begin{array}{c}\text { Varietas }^{3} \\
\text { Unggul }^{3}\end{array}$ & $\begin{array}{c}\text { Varietas } \\
\text { biasa }\end{array}$ & $\begin{array}{c}\text { Variaetas } \\
\text { Unggul }\end{array}$ \\
\hline 0,5 & 1,20 & 1,20 & 1,10 & 1,10 \\
\hline 1 & 1,20 & 1,27 & 1,10 & 1,10 \\
\hline 1,5 & 1,32 & 1,33 & 1,10 & 1,05 \\
\hline 2 & 1,40 & 1,30 & 1,10 & 1,05 \\
\hline 2,5 & 1,35 & 1,30 & 1,10 & 0,95 \\
\hline 3 & 1,24 & 0 & 1,05 & \\
\hline $\begin{array}{l}3,5 \\
4\end{array}$ & 1,12 & & 0,95 & \\
\hline
\end{tabular}

Plant coefficients are given to link evapotranspiration (ETo) with reference plant evapotranspiration (ETtanam) and are used in the Penman formula. The coefficient used must be based on continuous experience [5]

Table 2.7. Price of paddy crop coefficient

(KP 01, StandarPerencanaanIrigasi, 2010)

Table 2.8. The price of the coefficient of sugarcane

(KP 01, StandarPerencanaanlrigasi, 2010) 
Table 2.9. Price of Palawija plant coefficient

\begin{tabular}{|c|c|c|c|c|c|c|c|c|c|c|c|c|c|c|c|}
\hline Tanaman & $\begin{array}{c}\text { Jangka } \\
\text { tumbuh/ } \\
\text { hari }\end{array}$ & $\begin{array}{c}1 / 2 \\
\text { bulan } \\
\text { No. }\end{array}$ & 1 & 2 & 3 & 4 & 5 & 6 & 7 & 8 & 9 & 10 & 11 & 12 & 13 \\
\hline Kedelai & 85 & & 0,5 & 0,75 & 1,0 & 1,0 & 0,82 & $0,45^{*}$ & & & & & & & \\
\hline Jagung & 80 & & 0,5 & 0,59 & 0,96 & 1,05 & 1,02 & $0,95=$ & & & & & & & \\
\hline $\begin{array}{l}\text { Kacang } \\
\text { tanah }\end{array}$ & 130 & & 0,5 & 0,51 & 0,66 & 0,85 & 0,95 & 0,95 & 0,95 & 0,55 & $0,55^{*}$ & & & & \\
\hline Bawang & 70 & & 0,5 & 0,51 & 0,69 & 0,90 & $0,95=$ & & & & & & & & \\
\hline Buncis & 75 & & 0,5 & 0,64 & 0,89 & 0,95 & 0,88 & & & & & & & & \\
\hline Kapas & 195 & & 0,5 & 0,5 & 0,58 & 0,75 & 0,91 & 1,04 & 1,05 & 1,05 & 1,05 & 0,78 & 0,65 & 0,65 & 0,65 \\
\hline
\end{tabular}

\section{Effective Rainfall}

Effective rainfall is determined by the amount of $R_{80}$ which is the amount of rainfall that can be exceeded as much as $80 \%$ or in other words exceeded 8 times out of 10 times. In other words, the amount of rainfall smaller than $R_{80}$ has a possibility of only $20 \%$ [1]

When stated with the formula is as follows:

$$
\begin{aligned}
& R_{80}=\frac{m}{n-1}, m=R_{80} x(n+1) \\
& \text { Information : } \\
& \mathrm{R} 80 \quad=80 \% \text { Rainfall } \\
& \mathrm{n} \quad=\text { Amount of data } \\
& \mathrm{m} \quad=\text { Selected rainfall ranking }
\end{aligned}
$$
time. [1]

The effective rainfall for rice is $70 \%$ of the mid-monthly rainfall exceeding $80 \%$ of that

$$
\operatorname{Re}_{\text {padi }}=\frac{R_{80} \times 0.7}{\text { Period of observation }}
$$

For secondary crops is determined by a monthly period ( $50 \%$ fulfilled) associated with the plant ET table - monthly average and monthly average rainfall [1]

Information :

$$
\text { Re }_{\text {palawija }}=\frac{R_{80} \times 0.5}{\text { Period of observation }}
$$

$\mathrm{Re}$ (rice) = Effective rainfall for rice rice field $(\mathrm{mm} / \mathrm{hr})$

$\operatorname{Re}($ Palawija $)=$ Effective rainfall for Palawija $(\mathrm{mm} / \mathrm{hr})$

R80 $=$ The level of rain that occurs with certain level of confidence $(\mathrm{mm})$

\section{Land Preparation (LP)}

For the calculation of irrigation needs during land preparation, a method developed by van de Goor and Zijlstra (1968) was used [8]. The method is based on a constant water rate in 1 / sec over the period of land preparation and produces the following formula:

$$
\begin{array}{ll}
\mathrm{M} & =\mathrm{E}_{0}+\mathrm{P}=1,1 \mathrm{ET}_{0}+\mathrm{P} \\
\mathrm{Pd} & =\frac{M e^{k}}{e^{k}-1}
\end{array}
$$

Information:

$\mathrm{e}=$ Constants $(2.71828)$

$\mathrm{Pd} \quad=$ Irrigation water needs at the rice field level (mm.day)

$\mathrm{M} \quad=$ Need for water to replace losses water due to evaporation and percolation in the rice fieldssaturated $\mathrm{M}=\mathrm{Eo}+\mathrm{P}(\mathrm{mm} /$ day $)$

Eo $\quad=$ Open water evaporation taken 1.1 Eto during land preparation ( $\mathrm{mm} /$ day)

$\mathrm{P}=$ Percolation

$\mathrm{k}=\mathrm{MT} / \mathrm{S}$

$\mathrm{T}=$ Duration of land preparation (days)

$\mathrm{S}=\quad=$ Need for water, for added supply with a

$30 \mathrm{~mm}$ water layer, ie $200+50=250 \mathrm{~mm}$, if

there is a high land rest inundation of $300 \mathrm{~mm}$ 


\section{Use (ETc)}

Consumptive use is the amount of water used by plants for the photosynthesis of these plants. Consumptive use is calculated by the following formula:

Etc $=\mathrm{Kc}$. Eto

Information:

Etc = Evapotranspiration of plants $(\mathrm{mm} / \mathrm{day})$

Eto = Evapotranspiration of reference plants

( $\mathrm{mm} /$ day)

$\mathrm{Kc} \quad=$ crop coefficient

Source: (Sidharta, 1997: 31)

\section{Location and Seepage (P)}

The rate of percolation is very dependent on the properties of the soil. Data on percolation will be obtained from soil capability studies. The soil graduation test will be part of this investigation.

Based on the type of soil, the percolation power can be grouped into:

a. Sandy Loam with percolation 3-6 $\mathrm{mm} /$ day

b. Loam with percolation power of $2-3 \mathrm{~mm} /$ day

c. Clay loam with a insulation power of 1-2 mm / day.

\section{Substitution of Air Lines (WLR)}

After fertilization needs to be scheduled and replace the water layer as needed. Replacement is estimated at 2 times $50 \mathrm{~mm}$ each month and two months after transplantation (or $3.3 \mathrm{~mm} /$ day for $1 / 2 \mathrm{month}$ ).

\section{Irrigation Efficiency}

Irrigation Efficiency is the ratio of the amount of irrigation water used and discharged as stated in (\%). A quarter or one third of the amount of water taken will be lost before the water reaches the rice fields caused by exploitation, evaporation and location. Therefore it is necessary to calculate to obtain the amount of water needed by the intake.

The overall efficiency value is calculated with the following values:

$\mathrm{Ef}=$ tertiary tissue efficiency $60 \% \times$ efficiency secondary tissue $90 \% \times$ tissue

efficiency primary $90 \%$

$=65 \%$

\section{Kebutuhan Air di Saluran Intake (DR)}

Kebutuhanpengambilanuntukpadidanpalawijaadalahjumlah debit air yang dibutuhkanoleh 1 (satu) hektarsawah, digunakanrumus :

$\mathrm{DR}=\mathrm{NFR} /($ ef $\times 8,64)$

Information :

$$
\begin{array}{ll}
\mathrm{DR} & =\text { Retrieval requirement }(\mathrm{I} / \mathrm{sec} / \mathrm{ha}) \\
\mathrm{NFR} & =\text { Rice field water requirements }(\mathrm{mm} / \mathrm{day}) \\
\mathrm{Ef} & =\text { Irrigation Efficiency, Usually taken } 65 \%
\end{array}
$$

$1 / 8.64=$ unit conversion rate $(\mathrm{mm} /$ day $)$

\section{Water Balance}

Water balance calculation is carried out to check whether the available water is sufficient to meet the irrigation water requirements in the project concerned. Calculations are based on weekly or semi-monthly periods.

Three main elements are distinguished:
a. - Water availability
b. - Water Needs
c. - Water balance. 


\section{Planting Patterns}

Planting pattern is the most important way in planting system planning. The purpose of holding a planting system is to set the time, place, type and area of plants in the irrigation area. The purpose of the planting system is to utilize the irrigation water supply as effectively and efficiently as possible so that the plants can grow well.

Based on the understanding of planting system as above there are four factors that must be regulated, namely:

1. Early Planting

2. Types of Plants

3. Area

4. Denit available

5. Types of Planting Patterns, Determination of the type of cropping patterns adapted to the available water discharge at each planting season. Types of cropping patterns of an irrigation area can be classified into:
1) Rice
2) Rice - Rice - Palawija
3) Rice - Palawija - Palawija

\section{Research sites}

\section{Methodology}

Location of the study was conducted in the Solok Regency Irrigation Area, geographically Solok Regency is between 01020 '27' 'and 010 2' 39 " south latitude and 1000 33 ' 43 ' 'East Longitude. For more details about the location of work presented on the following map:

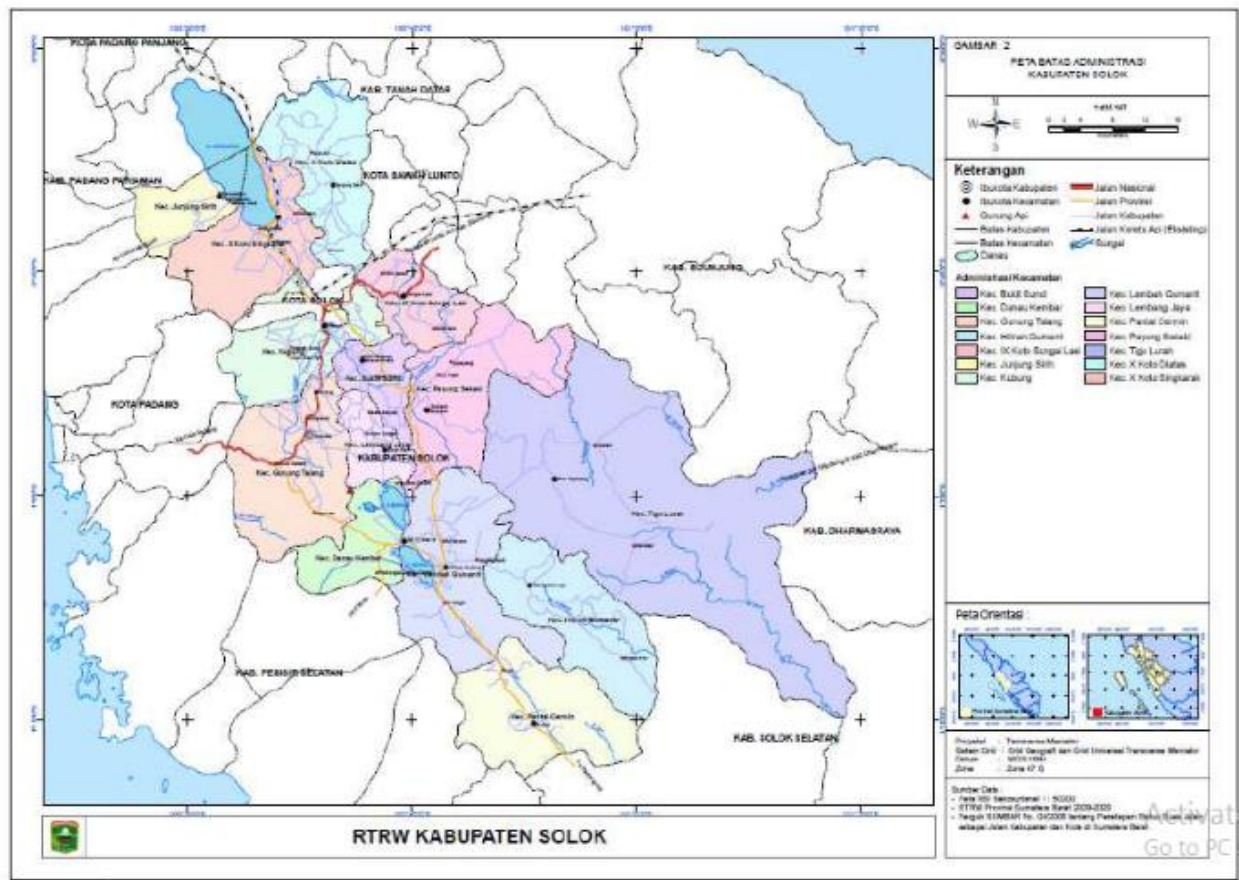

Figure 4

Rainfall data used is rainfall data in 2009 - 2018, in the rainfall analysis using the Thiessen method where the watershed area is 3,738 ha and the area of influence is based on 3 observation stations:

6. 1. KayuAro Station

7. 2. TelukBayur Maritime Methodology Station

8. 3. Padang Panjang Geophysical Station 


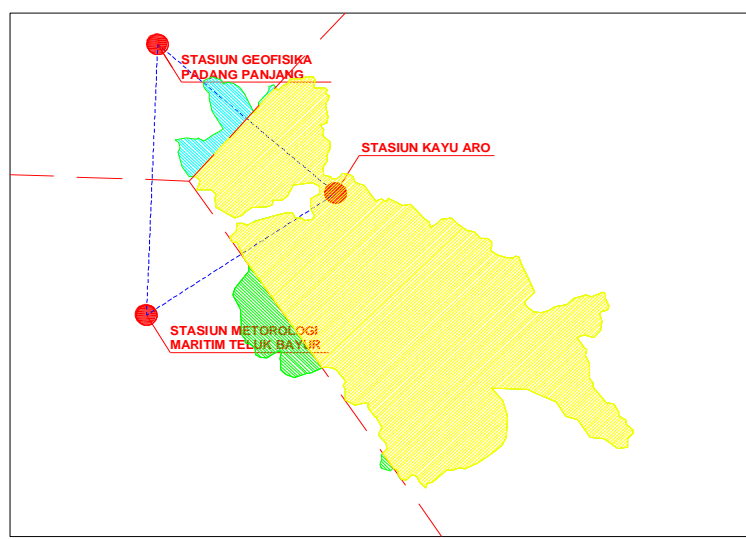

Figure5 : Map of Area of Influence

\section{Steps - Steps for Research}

The steps - the workmanship of the research can be seen in Figure Study Flowchart below:

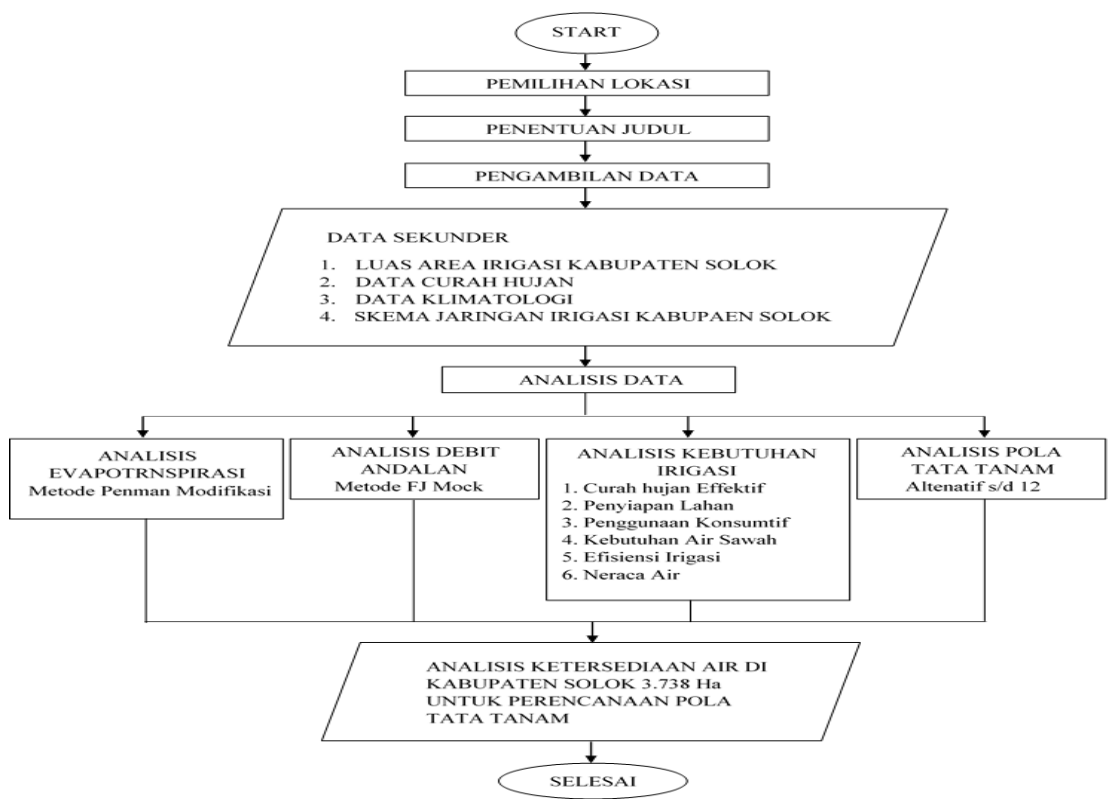

Figure7: Research Study Flow Chart

\section{Data Analysis}

\section{Calculating Potential Evapotranspiration (ETo)}

Plant evapotranspiration is a crop water requirement needed for plant growth, which is the result of evapotranspiration with plant coefficients. The value of this evapotranspiration is to estimate the water requirements for paddy fields.

From using the formula above we get the Evapotranspiration value: 


\section{Evapotranspiration Table (ETo)}

\begin{tabular}{|c|l|c|c|}
\hline No & \multicolumn{1}{|c|}{ B ulan } & Satuan & Nilai ETo \\
\hline 1 & Januari & $\mathrm{mm} /$ hari & 4,173 \\
\hline 2 & Februari & $\mathrm{mm} /$ hari & 4,675 \\
\hline 3 & Maret & $\mathrm{mm} /$ hari & 4,553 \\
\hline 4 & April & $\mathrm{mm} /$ hari & 4,471 \\
\hline 5 & Mei & $\mathrm{mm} /$ hari & 3,846 \\
\hline 6 & Juni & $\mathrm{mm} /$ hari & 3,353 \\
\hline 7 & Juli & $\mathrm{mm} /$ hari & 3,630 \\
\hline 8 & Agustus & $\mathrm{mm} /$ hari & 4,234 \\
\hline 9 & September & $\mathrm{mm} /$ hari & 8,638 \\
\hline 10 & Oktober & $\mathrm{mm} /$ hari & 3,160 \\
\hline 11 & November & $\mathrm{mm} /$ hari & 4,012 \\
\hline 12 & Desember & $\mathrm{mm} /$ hari & 3,828 \\
\hline
\end{tabular}

\section{GRAFIK EVAPOTRANSPIRASI (Eto)}

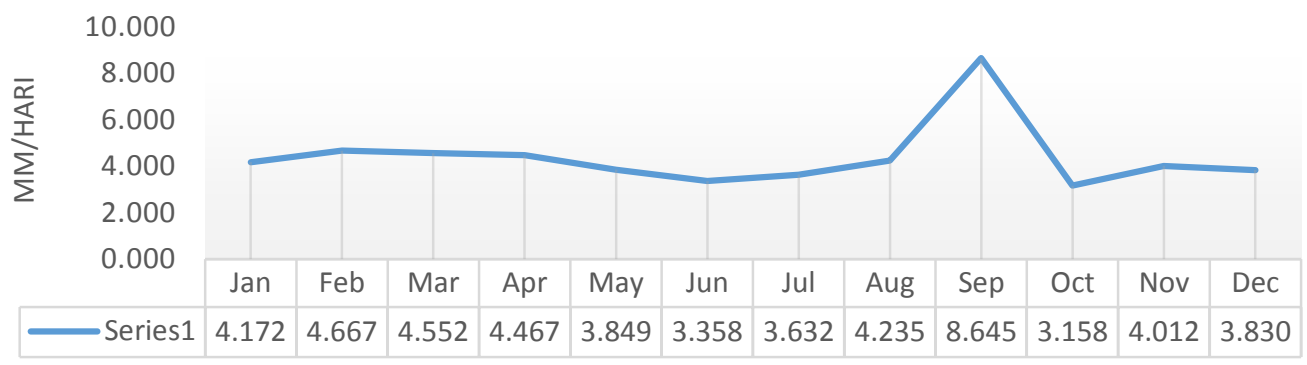

Source: Data Processing

\section{Mainstay Debit Calculation}

The mainstay discharge is generally analyzed as an average flow of a 10-year period taking into account the water needed from the downstream river taking to determine the paddy fields that can be drained.

\begin{tabular}{|c|c|c|c|c|c|c|}
\hline \multirow{3}{*}{ No } & \multirow{3}{*}{ B ulan } & \multirow{3}{*}{ Satuan } & \multicolumn{4}{|c|}{ Debit Andalan } \\
\hline & & & \multicolumn{2}{|c|}{ Q80 } & \multicolumn{2}{|c|}{ Q50 } \\
\hline & & & $\mathbf{I}$ & II & $\mathbf{I}$ & II \\
\hline 1 & Januari & $\mathrm{mm} / \mathrm{hari}$ & 8,352 & 9,228 & 5,220 & 5,767 \\
\hline 2 & Februari & $\mathrm{mm} / \mathrm{hari}$ & 7,331 & 4,564 & 4,582 & 2,852 \\
\hline 3 & Maret & $\mathrm{mm} / \mathrm{hari}$ & 6,848 & 7,022 & 4,280 & 4,389 \\
\hline 4 & April & $\mathrm{mm} / \mathrm{hari}$ & 10,482 & 8,343 & 6,552 & 5,214 \\
\hline 5 & Mei & $\mathrm{mm} / \mathrm{hari}$ & 4,897 & 7,704 & 3,061 & 4,815 \\
\hline 6 & Juni & $\mathrm{mm} /$ hari & 5,287 & 6,307 & 3,304 & 3,942 \\
\hline 7 & Juli & $\mathrm{mm} / \mathrm{hari}$ & 6,797 & 6,171 & 4,248 & 3,857 \\
\hline 8 & \begin{tabular}{|l|} 
Agustus \\
\end{tabular} & $\mathrm{mm} / \mathrm{hari}$ & 6,046 & 6,178 & 3,779 & 3,861 \\
\hline 9 & \begin{tabular}{|l|} 
September \\
\end{tabular} & $\mathrm{mm} / \mathrm{hari}$ & 6,483 & 9,391 & 4,052 & 5,869 \\
\hline 10 & \begin{tabular}{|l|} 
Oktober \\
\end{tabular} & $\mathrm{mm} / \mathrm{hari}$ & 10,102 & 6,353 & 6,314 & 3,970 \\
\hline 11 & November & $\mathrm{mm} /$ hari & 6,032 & 10,013 & 3,770 & 6,258 \\
\hline 12 & Desember & $\mathrm{mm} / \mathrm{hari}$ & 6,245 & 3,930 & 3,903 & 2,456 \\
\hline
\end{tabular}




\section{GARFIK DEBIT ANDALAN}
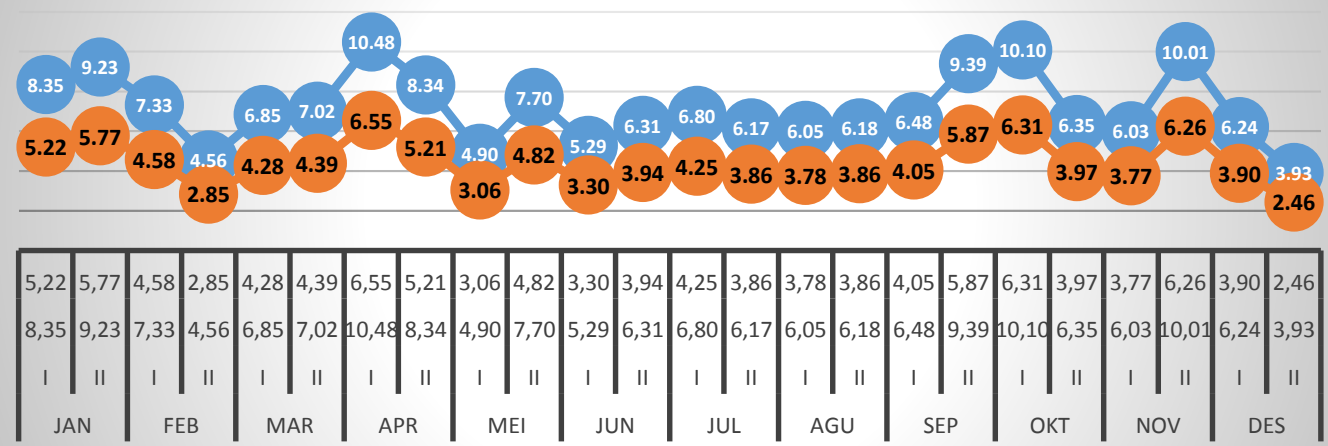

$\longrightarrow$ Q8000 $\longrightarrow$ Q5000

From the above table it can be seen that the maximum reliable discharge occurs in April of the 1st Week with Q80 of 10.41 Liters / sec / hectare and Q50 of 6.55 Liters / sec / hectare, while the minimum mainstay discharge occurs in December with Q80 was 3.93 liters / second / hectare and Q50 was 2.46 liters / second / hectare.

\section{Irrigation Water Needs Analysis Effective Rainfall}

The rainfall data used is semi-monthly average rainfall data. Design rain with probabilities $\mathrm{R} 50$ and $\mathrm{R} 80$ can be determined by limiting the ranking of monthly rainfall amounts from the smallest to the largest data based on annual rainfall.

Calculation of average rainfall data in this study uses theissen method

Data Ranking Table Monthly rainfall amounts from the smallest data to the biggest data in 2009-2018

\begin{tabular}{|r|r|r|r|r|r|r|r|r|r|r|r|}
\hline \multicolumn{2}{|c|}{ Januari } & \multicolumn{2}{c|}{ Februari } & \multicolumn{2}{c|}{ Maret } & \multicolumn{2}{c|}{ April } & \multicolumn{2}{|c|}{ Mei } & \multicolumn{2}{c|}{ Juni } \\
\hline Tahun & \multicolumn{1}{|c|}{ Jumlah } & \multicolumn{1}{c|}{ Tahun } & Jumlah & \multicolumn{1}{c|}{ Tahun } & \multicolumn{1}{c|}{ Jumlah } & Tahun & Jumlah & Tahun & Jumlah & Tahun & Jumlah \\
\hline 2018 & 28,488 & 2016 & 35,394 & 2017 & 105,000 & 2014 & 157,935 & 2015 & 43,409 & 2015 & 56,986 \\
\hline 2015 & 85,939 & 2014 & 54,505 & 2012 & 107,910 & 2017 & 164,596 & 2011 & 85,773 & 2012 & 79,385 \\
\hline 2012 & 99,346 & 2015 & 117,096 & 2015 & 127,845 & 2009 & 178,295 & 2009 & 88,258 & 2014 & 96,904 \\
\hline 2016 & 156,286 & 2011 & 119,013 & 2014 & 160,735 & 2015 & 178,728 & 2013 & 98,037 & 2013 & 99,961 \\
\hline 2017 & 202,402 & 2009 & 119,644 & 2016 & 211,594 & 2011 & 192,383 & 2016 & 150,387 & 2009 & 125,931 \\
\hline 2013 & 207,735 & 2010 & 150,494 & 2010 & 221,791 & 2013 & 209,786 & 2012 & 161,972 & 2011 & 149,129 \\
\hline 2011 & 226,446 & 2018 & 201,701 & 2013 & 296,722 & 2012 & 256,523 & 2010 & 209,081 & 2018 & 151,558 \\
\hline 2014 & 233,058 & 2017 & 262,769 & 2018 & 299,647 & 2018 & 258,174 & 2017 & 243,161 & 2010 & 166,354 \\
\hline 2009 & 244,303 & 2013 & 293,488 & 2009 & 333,723 & 2016 & 267,710 & 2014 & 284,760 & 2016 & 175,556 \\
\hline 2010 & 284,998 & 2012 & 345,409 & 2011 & 351,363 & 2010 & 280,055 & 2018 & 418,881 & 2017 & 177,257 \\
\hline
\end{tabular}

\begin{tabular}{|r|r|r|r|r|r|r|r|r|r|r|r|}
\hline \multicolumn{2}{|c|}{ Juli } & \multicolumn{2}{c|}{ Agustus } & \multicolumn{2}{c|}{ September } & \multicolumn{2}{c|}{ Oktober } & \multicolumn{2}{c|}{ November } & \multicolumn{2}{c|}{ Desember } \\
\hline Tahun & \multicolumn{1}{c|}{ Jumlah } & \multicolumn{1}{|c|}{ Tahun } & \multicolumn{1}{|c|}{ Jumlah } & \multicolumn{1}{c|}{ Tahun } & \multicolumn{1}{|c|}{ Jumlah } & Tahun & Jumlah & Tahun & \multicolumn{1}{c}{ Jumlah } & Tahun & Jumlah \\
\hline 2016 & 56,892 & 2015 & 63,215 & 2012 & 74,998 & 2015 & 107,257 & 2015 & 88,472 & 2015 & 94,891 \\
\hline 2017 & 64,560 & 2018 & 96,147 & 2015 & 103,164 & 2014 & 123,195 & 2016 & 179,671 & 2009 & 103,982 \\
\hline 2015 & 65,093 & 2017 & 102,766 & 2014 & 114,154 & 2013 & 208,821 & 2009 & 230,437 & 2011 & 111,874 \\
\hline 2011 & 76,773 & 2013 & 113,655 & 2016 & 126,840 & 2010 & 211,388 & 2012 & 232,716 & 2010 & 112,377 \\
\hline 2009 & 97,368 & 2016 & 142,366 & 2017 & 149,890 & 2016 & 220,454 & 2011 & 245,957 & 2016 & 131,074 \\
\hline 2018 & 99,912 & 2014 & 154,719 & 2013 & 167,104 & 2009 & 240,661 & 2018 & 276,177 & 2014 & 137,266 \\
\hline 2014 & 142,009 & 2012 & 180,097 & 2018 & 210,361 & 2011 & 250,715 & 2010 & 279,092 & 2012 & 178,019 \\
\hline 2010 & 183,453 & 2010 & 183,160 & 2011 & 243,504 & 2012 & 260,755 & 2017 & 287,673 & 2017 & 180,434 \\
\hline 2012 & 194,750 & 2011 & 191,889 & 2009 & 250,424 & 2017 & 311,828 & 2014 & 339,597 & 2013 & 308,044 \\
\hline 2013 & 243,255 & 2009 & 207,415 & 2010 & 262,536 & 2018 & 424,927 & 2013 & 404,462 & 2018 & 361,327 \\
\hline
\end{tabular}

After obtaining the rainfall value data from the smallest to the largest value, then the data is presented in the semi-monthly rainfall data, as shown in the following table: 
:: IJEEIT ::

(International Journal of Electrical Engineering and Information Technology)

Ranking data table of Half-Monthly Rainfall in 2009-2018

\begin{tabular}{|c|c|c|c|c|c|c|c|c|c|c|c|c|}
\hline \multirow{2}{*}{ Tahun } & \multicolumn{2}{|c|}{ Jan } & \multicolumn{2}{|c|}{ Feb } & \multicolumn{2}{|c|}{ Mar } & \multicolumn{2}{|c|}{ Apr } & \multicolumn{2}{|c|}{ Mei } & \multicolumn{2}{|c|}{ Jun } \\
\hline & I & II & I & II & I & II & I & II & I & II & I & II \\
\hline 2009 & 58,84 & $\begin{array}{l}185,46 \\
\end{array}$ & 21,16 & 98,48 & 238,37 & 95,36 & $\begin{array}{ll}71,26 \\
\end{array}$ & \begin{tabular}{|l|}
107,03 \\
\end{tabular} & \begin{tabular}{l|l|}
17,61 \\
\end{tabular} & \begin{tabular}{ll|}
70,64 \\
\end{tabular} & 433,73 & 82,20 \\
\hline 2010 & 158,40 & 126,60 & 100,15 & 50,35 & 131,75 & 90,04 & 194,38 & \begin{tabular}{|l|}
85,67 \\
\end{tabular} & 66,28 & 142,80 & 43,25 & 123,10 \\
\hline 2011 & 52,05 & 174,40 & 28,46 & 90,55 & 255,77 & 95,59 & 68,41 & 123,97 & 7,45 & $\begin{array}{l}78,32 \\
\end{array}$ & 55,64 & 93,49 \\
\hline 2012 & 71,69 & 27,66 & 223,59 & 121,82 & 60,71 & 47,20 & 143,23 & 113,29 & 79,62 & 82,35 & 33,31 & 46,07 \\
\hline 2013 & 50,46 & 157,27 & 226,31 & 67,18 & 56,78 & 239,94 & 80,29 & 129,49 & 54,14 & 43,90 & 54,89 & 45,07 \\
\hline 2014 & 174,60 & 58,46 & 45,34 & 9,16 & 75,90 & 84,83 & 60,56 & 97,38 & 126,33 & 158,43 & 76,30 & 20,60 \\
\hline 2015 & 24,89 & 61,05 & 42,09 & 75,01 & 67,57 & 60,28 & 53,26 & 125,46 & 26,35 & 17,06 & 36,55 & 20,44 \\
\hline 2016 & 33,75 & 122,54 & 12,98 & 22,41 & 89,73 & 121,86 & 120,02 & 147,69 & 25,00 & 125,38 & 127,94 & 47,62 \\
\hline 2017 & 135,91 & 66,49 & 225,05 & 37,72 & 27,42 & 77,58 & 72,45 & 92,15 & 33,38 & 209,78 & 145,14 & 32,12 \\
\hline 2018 & 8,59 & 19,89 & 121,18 & 80,53 & 198,60 & 101,04 & 173,28 & 84,90 & 241,35 & 177,53 & 3,92 & 147,64 \\
\hline
\end{tabular}

\begin{tabular}{|c|c|c|c|c|c|c|c|c|c|c|c|c|}
\hline \multirow{2}{*}{ Tahun } & \multicolumn{2}{|c|}{ Jul } & \multicolumn{2}{|c|}{ Agu } & \multicolumn{2}{|c|}{ Sep } & \multicolumn{2}{|c|}{ Okt } & \multicolumn{2}{|c|}{ Nov } & \multicolumn{2}{|c|}{ Des } \\
\hline & $\mathbf{I}$ & II & $\mathbf{I}$ & II & $\mathbf{I}$ & II & I & II & I & II & I & II \\
\hline 2009 & 68,61 & 28,76 & 66,85 & 140,57 & 181,08 & 69,34 & 129,49 & 111,17 & 79,37 & 151,07 & 40,70 & 63,28 \\
\hline 2010 & 89,63 & 93,83 & 88,56 & 94,60 & 98,33 & 164,21 & 143,76 & 67,62 & 102,97 & 176,12 & 46,90 & 65,48 \\
\hline 2011 & 51,05 & 25,72 & 60,12 & 131,77 & 180,41 & 63,10 & 131,77 & 118,95 & 97,13 & 148,82 & 50,87 & 61,00 \\
\hline 2012 & 124,50 & 70,25 & 27,39 & 152,70 & 32,95 & 42,05 & 64,90 & 195,85 & 120,36 & 112,36 & 120,25 & 57,77 \\
\hline 2013 & 128,91 & 114,34 & 24,73 & 88,92 & 113,50 & 53,61 & 73,35 & 135,47 & 282,61 & 121,85 & 120,42 & 187,62 \\
\hline 2014 & 42,83 & 99,17 & 56,80 & 97,92 & 59,98 & 54,17 & 58,17 & 65,03 & 99,27 & 240,32 & 81,58 & 55,69 \\
\hline 2015 & 45,32 & 19,78 & 12,31 & 50,91 & 58,60 & 44,57 & 42,93 & 64,33 & 37,73 & 50,74 & 56,29 & 38,60 \\
\hline 2016 & 20,99 & 35,90 & 55,92 & 86,44 & 31,40 & 95,44 & 115,85 & 104,61 & 121,95 & 57,72 & 49,57 & 81,50 \\
\hline 2017 & 38,48 & 26,08 & 76,30 & 26,47 & 27,04 & 122,85 & 136,09 & 175,74 & 196,52 & 91,15 & 127,84 & 52,59 \\
\hline 2018 & 76,82 & 23,09 & 45,97 & 50,18 & 85,02 & 125,34 & 285,12 & 139,80 & 188,44 & 87,74 & 335,56 & 25,76 \\
\hline
\end{tabular}

Effective Rainfall Data Table (Re)

\begin{tabular}{|c|c|c|c|c|c|c|c|c|c|c|c|c|c|c|}
\hline \multirow[t]{2}{*}{$\mathrm{N}_{0}$} & \multirow[t]{2}{*}{ Bulan } & \multicolumn{2}{|c|}{ R80 } & \multicolumn{2}{|c|}{ R50 } & \multirow{2}{*}{$\begin{array}{c}\text { Jumlah } \\
\text { Hari } \\
\end{array}$} & \multicolumn{2}{|c|}{$\begin{array}{l}\text { R80 Efektif } \\
\text { (R80/JH) }\end{array}$} & \multicolumn{2}{|c|}{$\begin{array}{c}\text { R50 Efektif } \\
\text { (R50/JH) }\end{array}$} & \multicolumn{2}{|c|}{$\begin{array}{c}\text { Re Padi }(\operatorname{R} 80 x \\
0,7)\end{array}$} & \multicolumn{2}{|c|}{$\begin{array}{c}\text { Re Palawija (R80 } \\
\mathrm{x} 0,5)\end{array}$} \\
\hline & & I & II & I & II & & I & II & I & II & I & II & I & II \\
\hline 1 & Januari & 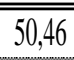 & $\bar{~} 157,27$ & $\overline{7 \overline{71,69}}$ & 27,66 & $\bar{~} 15,50$ & 3,26 & 10,15 & $\overline{4,63}$ & $\overline{17,78}$ & 2,28 & $\overline{7,10}$ & 2,31 & 0,899 \\
\hline 2 & Februari & 100,15 & 50,35 & 42,09 & 75,01 & 14,00 & 7,15 & 3,60 & 3,01 & 5,36 & 5,01 & 2,52 & 1,50 & 2,68 \\
\hline 3 & Maret & 131,75 & 90,04 & 67,57 & 60,28 & 15,50 & 8,50 & 5,81 & 4,36 & 3,89 & 5,95 & 4,07 & 2,18 & 1,94 \\
\hline 4 & April & 80,29 & 129,49 & 71,26 & 107,03 & 15,00 & 5,35 & 8,63 & 4,75 & 7,14 & 3,75 & 6,04 & 2,38 & 3,57 \\
\hline 5 & Mei & 79,62 & 82,35 & 17,61 & 70,64 & 15,50 & 5,14 & 5,31 & 1,14 & 4,56 & 3,60 & 3,72 & 0,57 & 2,28 \\
\hline 6 & Juni & 55,64 & 93,49 & 76,30 & 20,60 & 15,00 & 3,71 & 6,23 & 5,09 & 1,37 & 2,60 & 4,36 & 2,54 & 0,69 \\
\hline 7 & Juli & 76,82 & 23,09 & 45,32 & 19,78 & 15,50 & 4,96 & 1,49 & 2,92 & 1,28 & 3,47 & 1,04 & 1,46 & 0,64 \\
\hline 8 & Agustus & 56,80 & 97,92 & 76,30 & 26,47 & 15,50 & 3,66 & 6,32 & 4,92 & 1,71 & 2,57 & 4,42 & 2,46 & 0,85 \\
\hline 9 & September & 113,50 & 53,61 & 59,98 & 54,17 & 15,00 & 7,57 & 3,57 & 4,00 & 3,61 & 5,30 & 2,50 & 2,00 & 1,81 \\
\hline 10 & Oktober & 129,49 & 111,17 & 73,35 & 135,47 & 15,50 & 8,35 & 7,17 & 4,73 & 8,74 & 5,85 & 5,02 & 2,37 & 4,37 \\
\hline 11 & November & 188,44 & 87,74 & 79,37 & 151,07 & 15,00 & 12,56 & 5,85 & 5,29 & 10,07 & 8,79 & 4,09 & 2,65 & 5,04 \\
\hline 12 & Desember & 81,58 & 55,69 & 50,87 & 61,00 & 15,50 & 5,26 & 3,59 & 3,28 & 3,94 & 3,68 & 2,51 & 1,64 & 1,97 \\
\hline
\end{tabular}




\section{CURAH HUJAN EFFEKTIF}

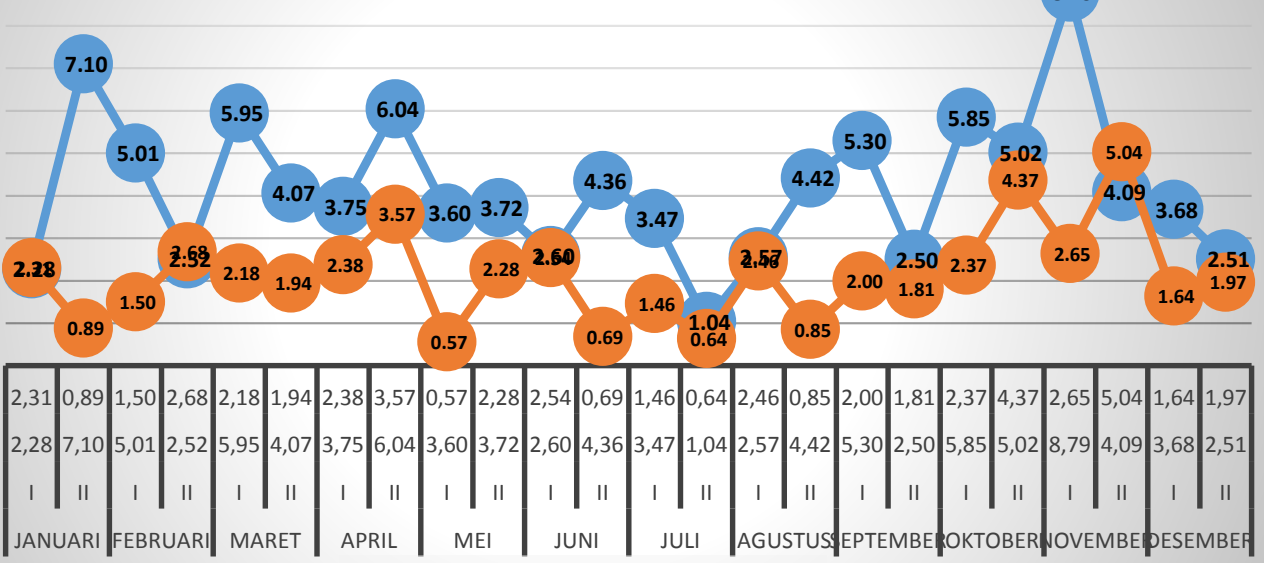

$\longrightarrow$ Re Padi $\rightleftharpoons$ Re Palawija

The biggest effective rainfall for rice plants occurred in November the first week, and the lowest was in July the second week, while for the crops crops the biggest effective rainfall occurred in November the second week, and the lowest occurred in November May 1st week

\section{Water Needs For Consumptive Plants (ETc)}

Plant consumptive needs are the amount of water used by plants for the photosynthesis process of these plants. The need for plants can be known by calculating the value of evapotranspiration which is influenced by plant coefficients (plant type, plant age and climatology).

\begin{tabular}{|c|c|c|c|c|c|c|c|c|c|c|}
\hline \multicolumn{2}{|c|}{ Bulan } & \multicolumn{2}{|c|}{ Pola Tata Tanam } & \multicolumn{2}{|c|}{ Koefisien Tanaman } & \multirow{2}{*}{\begin{tabular}{|c|}
$\begin{array}{c}\text { Rata- } \\
\text { Rata } \\
\text { Koefisien } \\
\text { Tanaman } \\
\text { (Kc) }\end{array}$ \\
\end{tabular}} & \multirow{2}{*}{\begin{tabular}{|c|}
$\begin{array}{c}\text { Evaporas } \\
\mathbf{i} \\
\text { Potensial } \\
\text { (ETO) }\end{array}$ \\
$\mathrm{mm} / \mathrm{hr}$ \\
\end{tabular}} & \multirow{2}{*}{\begin{tabular}{|c|}
$\begin{array}{c}\text { Penggun } \\
\text { aan Air } \\
\text { Konsumt } \\
\text { if (Etc) }\end{array}$ \\
$\mathrm{mm} / \mathrm{hr}$ \\
\end{tabular}} & \multirow[t]{2}{*}{$\begin{array}{l}\text { Rasio } \\
\text { Luas } \\
\text { (Etc) }\end{array}$} & \multirow{2}{*}{$\begin{array}{c}\begin{array}{c}\text { Etc* } \\
\text { Rasio } \\
\text { Luas }\end{array} \\
\mathbf{m m} / \mathrm{hr} \\
\end{array}$} \\
\hline & & & & K-1 & $K-2$ & & & & & \\
\hline \multirow[b]{2}{*}{ Januari } & $\mathbf{I}$ & PW & & 1,02 & 1,05 & 1,04 & 4,17 & 4,32 & 1,00 & 4,32 \\
\hline & II & PW & & 0,95 & 1,02 & 0,99 & 4,17 & 4,11 & 1,00 & 4,11 \\
\hline \multirow[b]{2}{*}{ Februari } & $\mathbf{I}$ & TrR & & & 0,95 & 0,48 & 4,67 & 2,22 & 0,75 & 1,67 \\
\hline & II & $\mathbf{L P}$ & & & & 0,00 & 4,67 & 0,00 & 0,25 & 0,00 \\
\hline \multirow[b]{2}{*}{ Maret } & $\mathbf{I}$ & TW2 & & 1,20 & & 0,60 & 4,55 & 2,73 & 0,25 & 0,68 \\
\hline & II & PD & & 1,27 & 1,20 & 1,24 & 4,55 & 5,62 & 0,75 & 4,22 \\
\hline \multirow[b]{2}{*}{ April } & $\mathbf{I}$ & PD & & 1,33 & 1,27 & 1,30 & 4,47 & 5,81 & 1,00 & 5,81 \\
\hline & II & PD & & 1,30 & 1,33 & 1,32 & 4,47 & 5,88 & 1,00 & 5,88 \\
\hline \multirow[b]{2}{*}{ Mei } & $\mathbf{I}$ & PD & & 1,30 & 1,30 & 1,30 & 3,85 & 5,00 & 1,00 & 5,00 \\
\hline & II & PD & & 0,00 & 1,33 & 0,67 & 3,85 & 2,56 & 1,00 & 2,56 \\
\hline \multirow[b]{2}{*}{ Juni } & $\mathbf{I}$ & BTERQ & & & 1,30 & 0,65 & 3,35 & 2,18 & 0,75 & 1,63 \\
\hline & II & B ERO & 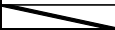 & & & 0,00 & 3,35 & 0,00 & 0,25 & 0,00 \\
\hline \multirow[b]{2}{*}{ Juli } & $\mathbf{I}$ & TR & & & & 0,00 & 3,63 & 0,00 & 0,00 & 0,00 \\
\hline & II & LP & P & & & 0,00 & 3,63 & 0,00 & 0,00 & 0,00 \\
\hline \multirow[b]{2}{*}{ Agustus } & $\mathbf{I}$ & PAN & & 1,20 & & 0,60 & 4,23 & 2,54 & 0,25 & 0,64 \\
\hline & II & PADI & 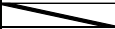 & 1,27 & 1,20 & 1,24 & 4,23 & 5,23 & 0,75 & 3,92 \\
\hline \multirow[b]{2}{*}{ September } & $\mathbf{I}$ & PADI & & 1,33 & 1,27 & 1,30 & 8,64 & 11,23 & 1,00 & 11,23 \\
\hline & II & PADI & & 1,30 & 1,33 & 1,32 & 8,64 & 11,36 & 1,00 & 11,36 \\
\hline \multirow[b]{2}{*}{ Oktober } & $\mathbf{I}$ & PADI & & 1,30 & 1,30 & 1,30 & 3,16 & 4,11 & 1,00 & 4,11 \\
\hline & II & PADI & & 0,00 & 1,30 & 0,65 & 3,16 & 2,05 & 1,00 & 2,05 \\
\hline \multirow{2}{*}{ November } & I & ThK & & 0,50 & 0,00 & 0,25 & 4,01 & 1,00 & 1,00 & 1,00 \\
\hline & II & $\mathbf{P W}$ & 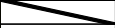 & 0,59 & 0,50 & 0,55 & 4,01 & 2,19 & 1,00 & 2,19 \\
\hline \multirow[b]{2}{*}{ Desember } & $\mathbf{I}$ & $\mathbf{P W}$ & & 0,96 & 0,59 & 0,78 & 3,83 & 2,97 & 1,00 & 2,97 \\
\hline & II & $\mathbf{P W}$ & & 1,05 & 0,96 & 0,53 & 3,83 & 2,01 & 1,00 & 2,01 \\
\hline
\end{tabular}




\section{Grafik Penggunaan Konsumtif Alternatif 7}

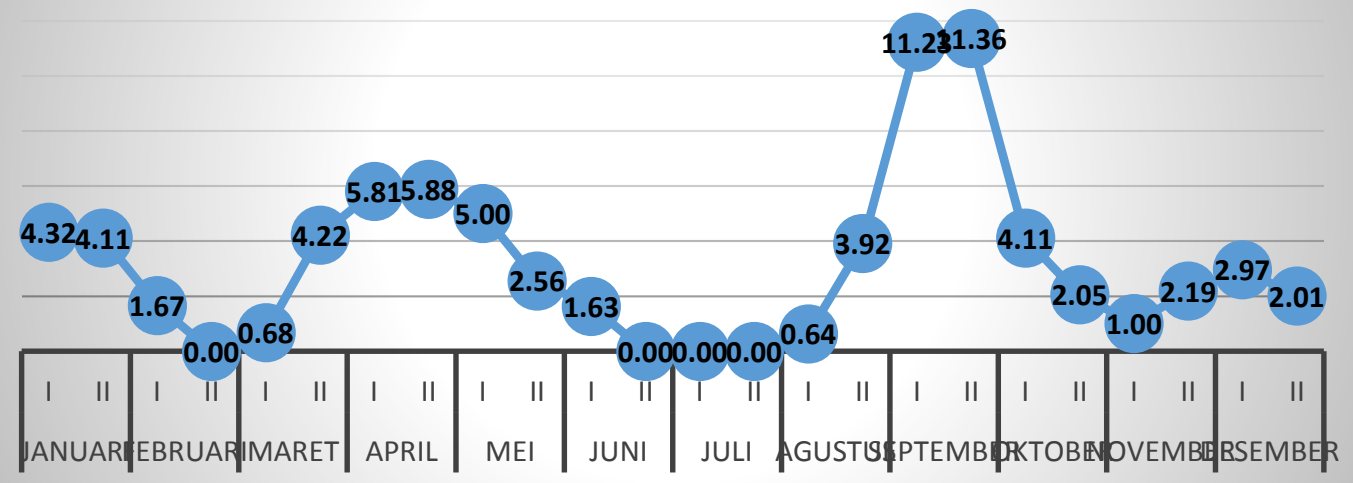

\section{Land Preparation (LP)} method.

Calculation of water requirements for land preparation is done by the Van de GoorZijlstra

\begin{tabular}{|c|c|c|c|c|c|c|c|c|c|c|c|c|c|c|}
\hline \multirow[b]{2}{*}{0.1} & \multirow[b]{2}{*}{ Perhitungan } & \multicolumn{13}{|c|}{ Bulan } \\
\hline & & Satuan & Jan & Feb & Mar & Apr & Mei & Juni & Juli & Agst & Sep & Okt & Nov & Des \\
\hline 1 & Eto & mm/hari & 4,172 & 4,667 & 4,552 & 4,467 & 3,849 & 3,358 & 3,632 & 4,235 & 8,645 & 3,158 & 4,012 & 3,830 \\
\hline 2 & $\mathrm{E} 0=1,1 \times \mathrm{Et}$ & mm/hari & 4,590 & 5,134 & 5,008 & 4,913 & \begin{tabular}{|l|l|}
4,234 \\
\end{tabular} & \begin{tabular}{|l|l|}
3,694 \\
\end{tabular} & 3,996 & 4,659 & 9,509 & 3,474 & 4,414 & 4,212 \\
\hline 3 & $P$ & mm/hari & 2,00 & 2,00 & 2,00 & 2,00 & 2,00 & 2,00 & 2,00 & 2,00 & 2,00 & 2,00 & 2,00 & 2,00 \\
\hline 4 & $M=E 0+P$ & mm/hari & 6,590 & 7,134 & 7,008 & 6,913 & 6,234 & 5,694 & 5,996 & 6,659 & 11,509 & 5,474 & 6,414 & 6,212 \\
\hline 5 & $\mathrm{~T}$ & hari & 31 & 28 & 31 & 30 & 31 & \begin{tabular}{|c|}
30 \\
\end{tabular} & 31 & 31 & 30 & 31 & 30 & 31 \\
\hline 6 & $S$ & $\mathrm{~mm}$ & 250 & 250 & 250 & 250 & 250 & 300 & 250 & 250 & 250 & 250 & 250 & 250 \\
\hline & $\mathrm{k}=\mathrm{MxT} / \mathrm{S}$ & & 0,817 & 0,799 & 0,869 & 0,830 & 0,773 & 0,569 & 0,743 & 0,826 & 1,381 & 0,679 & 0,770 & 0,770 \\
\hline 8 & $\mathrm{e}$ & & 2,718 & 2,718 & 2,718 & 2,718 & 2,718 & 2,718 & 2,718 & 2,718 & 2,718 & 2,718 & 2,718 & 2,718 \\
\hline 9 & $\mathrm{e}^{\mathrm{k}}$ & & 2,264 & 2,223 & 2,384 & 2,292 & 2,166 & 1,767 & 2,103 & 2,283 & 3,979 & 1,971 & 2,159 & 2,160 \\
\hline 10 & $e^{k}-1$ & & 1,264 & 1,223 & 1,384 & 1,292 & 1,166 & 0,767 & 1,103 & 1,283 & 2,979 & 0,971 & 1,159 & 1,160 \\
\hline 1 & $\mathrm{Pd}$ & mm/hari & 11,804 & 12,967 & 12,070 & 12,263 & 11,580 & 13,117 & 11,431 & 11,848 & 15,373 & 11,110 & 11,948 & 11,566 \\
\hline
\end{tabular}

\section{Percolation}

The rate of percolation is very dependent on the properties of the soil. Data on percolation will be obtained from soil capability studies. The soil graduation test will be part of this investigation. (KP 01, Irrigation Planning Standards, 2010)

\begin{tabular}{|c|c|c|c|c|c|}
\hline \multicolumn{2}{|c|}{ Bulan } & \multirow{2}{*}{$\begin{array}{c}\begin{array}{c}\text { Pd } * \text { Rasio } \\
\text { Luas }\end{array} \\
\mathrm{mm} / \mathrm{hr} \\
\end{array}$} & \multirow{2}{*}{$\begin{array}{c}\text { Perkolasi } \\
\mathrm{mm} / \mathrm{hr} \\
\end{array}$} & \multirow{2}{*}{$\begin{array}{c}\begin{array}{c}\text { Rasio } \\
\text { Luas } \\
\text { Perkolasi }\end{array} \\
\end{array}$} & \multirow{3}{*}{\begin{tabular}{|c}
$\begin{array}{c}\text { Rasio luas } \\
\text { perkolasi } * \\
\text { Perkolasi }\end{array}$ \\
mm/hr \\
2,00
\end{tabular}} \\
\hline \multirow[b]{3}{*}{ Januari } & & & & & \\
\hline & $\mathbf{I}$ & $\mathrm{O}, \mathrm{OO}$ & 2,00 & $1, \mathrm{OO}$ & \\
\hline & II & 0,00 & 2,00 & $1, \mathrm{OO}$ & 2,00 \\
\hline \multirow[b]{2}{*}{ Februari } & $\mathbf{I}$ & 3,24 & 2,00 & 0,75 & 1,50 \\
\hline & II & 9,73 & 2,00 & 0,25 & 0,50 \\
\hline \multirow[b]{2}{*}{ Maret } & $\mathbf{I}$ & 9,05 & 2,00 & 0,25 & 0,50 \\
\hline & II & 3,02 & 2,00 & 0,75 & 1,50 \\
\hline \multirow[b]{2}{*}{ April } & $\mathbf{I}$ & 0,00 & 2,00 & 1,00 & 2,00 \\
\hline & II & 0,00 & 2,00 & 1,00 & 2,00 \\
\hline \multirow[b]{2}{*}{ Mei } & $\mathbf{I}$ & 0,00 & 2,00 & 1,00 & 2,00 \\
\hline & II & 0,00 & 2,00 & $1, \mathrm{OO}$ & 2,00 \\
\hline \multirow[b]{2}{*}{ Juni } & $\mathbf{I}$ & 0,00 & 2,00 & 0,75 & 1,50 \\
\hline & II & 0,00 & 2,00 & 0,25 & 0,50 \\
\hline \multirow[b]{2}{*}{ Juli } & $\mathbf{I}$ & 2,86 & 2,00 & 0,00 & $\mathrm{O}, \mathrm{OO}$ \\
\hline & II & 8,57 & 2,00 & 0,00 & $\mathrm{O}, \mathrm{OO}$ \\
\hline \multirow[b]{2}{*}{ Agustus } & $\mathbf{I}$ & 8,89 & 2,00 & 0,25 & 0,50 \\
\hline & II & 2,96 & 2,00 & 0,75 & 1,50 \\
\hline \multirow[b]{2}{*}{ September } & $\mathbf{I}$ & 0,00 & 2,00 & $1, \mathrm{OO}$ & 2,00 \\
\hline & II & 0,00 & 2,00 & 1,00 & 2,00 \\
\hline \multirow[b]{2}{*}{ Oktober } & $\mathbf{I}$ & 0,00 & 2,00 & 1,00 & 2,00 \\
\hline & II & 0,00 & 2,00 & 1,00 & 2,00 \\
\hline \multirow[b]{2}{*}{ November } & $\mathbf{I}$ & 0,00 & 2,00 & 1,00 & 2,00 \\
\hline & II & 0,00 & 2,00 & 1,00 & 2,00 \\
\hline \multirow[b]{2}{*}{ Desember } & $\mathbf{I}$ & 0,00 & 2,00 & 1,00 & 2,00 \\
\hline & II & 0,00 & 2,00 & 1,00 & 2,00 \\
\hline
\end{tabular}


Substitution of Water Layer (WLR)

\begin{tabular}{|c|c|c|c|c|}
\hline \multicolumn{2}{|c|}{ Bulan } & WLR & $\begin{array}{c}\text { Rasio } \\
\text { Luas WVLR }\end{array}$ & $\begin{array}{c}\text { WLR*Ras } \\
\text { io Luas }\end{array}$ \\
\hline \multirow[b]{2}{*}{ Januari } & $\mathbf{I}$ & 3,33 & 0,75 & 2,50 \\
\hline & II & 3,33 & 0,25 & 0,83 \\
\hline \multirow[b]{2}{*}{ Februari } & $\mathbf{I}$ & 3,33 & & $\mathrm{O}, \mathrm{OO}$ \\
\hline & II & 3,33 & & 0,00 \\
\hline \multirow[b]{2}{*}{ Maret } & $\mathbf{I}$ & 3,33 & & $\mathrm{O}, \mathrm{OO}$ \\
\hline & II & 3,33 & & $\mathrm{O}, \mathrm{OO}$ \\
\hline \multirow[b]{2}{*}{ April } & $\mathbf{I}$ & 3,33 & 0,25 & 0,83 \\
\hline & II & 3,33 & 0,75 & 2,50 \\
\hline \multirow[b]{2}{*}{ Mei } & $\mathbf{I}$ & 3,33 & 0,75 & 2,50 \\
\hline & II & 3,33 & 0,25 & 0,83 \\
\hline \multirow[b]{2}{*}{ Jumi } & $\mathbf{I}$ & 3,33 & & $\mathrm{O}, \mathrm{OO}$ \\
\hline & II & 3,33 & & $\mathrm{O}, \mathrm{OO}$ \\
\hline \multirow[b]{2}{*}{ Juli } & $\mathbf{I}$ & 3,33 & & $\mathrm{O}, \mathrm{OO}$ \\
\hline & II & 3,33 & & $\mathrm{O}, \mathrm{OO}$ \\
\hline \multirow[b]{2}{*}{ Agustus } & $\mathbf{I}$ & 3,33 & & $\mathrm{O}, \mathrm{OO}$ \\
\hline & II & 3,33 & & $\mathrm{O}, \mathrm{OO}$ \\
\hline \multirow[b]{2}{*}{ September } & $\mathbf{I}$ & 3,33 & 0,25 & 0,83 \\
\hline & II & 3,33 & 0,75 & 2,50 \\
\hline \multirow[b]{2}{*}{ Oktober } & $\mathbf{I}$ & 3,33 & 0,75 & 2,50 \\
\hline & II & 3,33 & 0,25 & 0,83 \\
\hline \multirow[b]{2}{*}{ November } & $\mathbf{I}$ & 3,33 & & $\mathrm{O}, \mathrm{OO}$ \\
\hline & II & 3,33 & & $\mathrm{O}, \mathrm{OO}$ \\
\hline \multirow[b]{2}{*}{ Desember } & $\mathbf{I}$ & 3,33 & 0,25 & 0,83 \\
\hline & II & 3,33 & 0,75 & 2,50 \\
\hline
\end{tabular}

So NFR is obtained

\begin{tabular}{|c|c|c|c|c|c|}
\hline \multirow{2}{*}{\multicolumn{2}{|c|}{ Bulan }} & \multirow{2}{*}{\multicolumn{2}{|c|}{$\begin{array}{c}\text { Kebutuhan Irigasi } \\
\text { (NFR) }\end{array}$}} & \multirow{4}{*}{$\begin{array}{c}\text { Efisiensi } \\
\% \\
0,65\end{array}$} & \multirow{4}{*}{$\begin{array}{c}\text { Intake } \\
\text { 1/dt/ha } \\
1,57\end{array}$} \\
\hline & & & & & \\
\hline & & \multirow{2}{*}{$\begin{array}{c}\mathrm{mm} / \mathrm{hr} \\
8,82 \\
\end{array}$} & \multirow{2}{*}{$\frac{1 / \mathrm{dt} / \mathrm{ha}}{1,02}$} & & \\
\hline & $\mathbf{I}$ & & & & \\
\hline Januari & II & 6,94 & 0,80 & 0,65 & 1,24 \\
\hline \multirow[b]{2}{*}{ Februari } & $\mathbf{I}$ & 1,40 & 0,16 & 0,65 & 0,25 \\
\hline & II & 7,71 & 0,89 & 0,65 & 1,37 \\
\hline \multirow[b]{2}{*}{ Maret } & $\mathbf{I}$ & 4,29 & 0,50 & 0,65 & 0,76 \\
\hline & II & 4,67 & 0,54 & 0,65 & 0,83 \\
\hline \multirow[b]{2}{*}{ April } & $\mathbf{I}$ & 4,90 & 0,57 & 0,65 & 0,87 \\
\hline & II & 4,34 & 0,50 & 0,65 & 0,77 \\
\hline \multirow[b]{2}{*}{ Mei } & $\mathbf{I}$ & 9,50 & 1,10 & 0,65 & 1,69 \\
\hline & II & 5,39 & 0,62 & 0,65 & 0,96 \\
\hline \multirow[b]{2}{*}{ Jumi } & $\mathbf{I}$ & 3,13 & 0,36 & 0,65 & 0,56 \\
\hline & II & 0,50 & 0,06 & 0,65 & 0,09 \\
\hline \multirow[b]{2}{*}{ Juli } & $\mathbf{I}$ & $-0,61$ & $-0,07$ & 0,65 & $-0,11$ \\
\hline & II & 7,53 & 0,87 & 0,65 & 1,34 \\
\hline \multirow[b]{2}{*}{ Agustus } & $\mathbf{I}$ & 7,46 & 0,86 & 0,65 & 1,33 \\
\hline & II & 3,96 & 0,46 & 0,65 & 0,71 \\
\hline \multirow[b]{2}{*}{ September } & $\mathbf{I}$ & 8,77 & 1,01 & 0,65 & 1,56 \\
\hline & II & 13,36 & 1,55 & 0,65 & 2,38 \\
\hline \multirow[b]{2}{*}{ Oktober } & $\mathbf{I}$ & 6,24 & 0,72 & 0,65 & 1,11 \\
\hline & II & 0,52 & 0,06 & 0,65 & 0,09 \\
\hline \multirow[b]{2}{*}{ November } & $\mathbf{I}$ & 0,36 & 0,04 & 0,65 & 0,06 \\
\hline & II & $-0,85$ & $-0,10$ & 0,65 & $-0,15$ \\
\hline \multirow[b]{2}{*}{ Desember } & $\mathbf{I}$ & 4,16 & 0,48 & 0,65 & 0,74 \\
\hline & II & 4,54 & 0,53 & 0,65 & 0,81 \\
\hline
\end{tabular}

\section{Grafik Kebutuhan Air Sawah (NFR)}

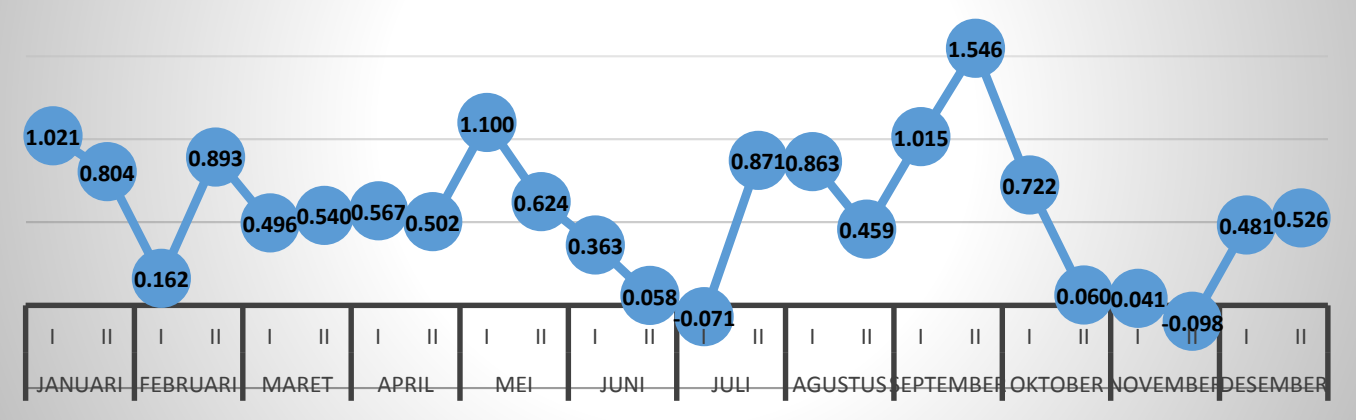




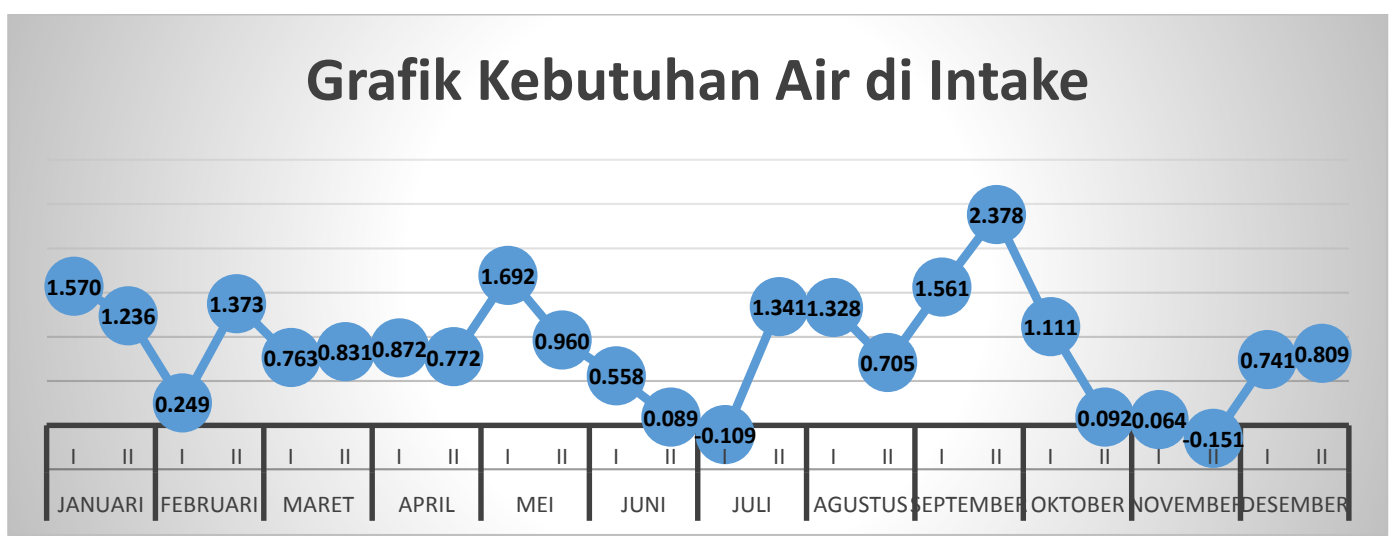

So we get the value of water demand in the intake channel in March $\mathrm{M}-1$ of $0.763 \mathrm{I} / \mathrm{sec}$ / ha, and for further calculations it is presented in the form of a table below.

\section{Water Balance}

Water balance calculation is carried out to check whether the available water is sufficient to meet the irrigation water requirements in the project concerned. Calculations are based on weekly or semi-monthly periods. Three main elements are distinguished:

d. Water availability

e. Water Needs

f. Water balance.

\begin{tabular}{|c|c|c|c|c|c|c|c|c|c|c|c|c|c|c|}
\hline \multirow[t]{2}{*}{10} & \multirow{2}{*}{$\begin{array}{l}\text { Bulan } \\
\text { Periode }\end{array}$} & \multirow{2}{*}{ Satuan } & \multicolumn{2}{|c|}{ Januari } & \multicolumn{2}{|c|}{ Februari } & \multicolumn{2}{|c|}{ Maret } & \multicolumn{2}{|c|}{ Apil } & \multicolumn{2}{|c|}{ Mei } & \multicolumn{2}{|c|}{ Juni } \\
\hline & & & $\mathrm{I}$ & II & $\mathrm{I}$ & II & $\mathrm{I}$ & II & $\mathrm{I}$ & II & $\mathrm{I}$ & II & $\mathrm{I}$ & II \\
\hline & Efsisensi irigasi (Eff) & $\%$ & 0,650 & 0,650 & 0,650 & 0,650 & 0,650 & 0,650 & 0,650 & 0,650 & 0,650 & 0,650 & 0,650 & 0,650 \\
\hline & Keboutuhan Air di Sal Intake (DR) & Votha & 1,570 & 1,236 & 0,249 & 1,373 & 0,763 & 0,831 & 0,872 & 0,772 & 1,692 & 0,960 & 0,558 & 0,089 \\
\hline 2 & Debit Andalan 080 & Votha & 8,352 & 9,228 & 7,331 & 4,564 & 6,848 & 7,022 & 10,482 & 8,343 & 4,897 & 7,704 & 5,287 & 6,307 \\
\hline & Neraca Air & Vdtha & 6,782 & 7,991 & 7,081 & 3,191 & 6,085 & 6,191 & 9,610 & 7,571 & 3,205 & 6,744 & 4,729 & 6,218 \\
\hline & Terpenulititidak & terpenuli & -1 & terpenth & terpenuhi & terpenuh & terpen & terpenuli & terpenuhi & terpenthe & terpenuli & terpenuhi & terpenuhi & eipentu \\
\hline
\end{tabular}

\begin{tabular}{|c|c|c|c|c|c|c|c|c|c|c|c|c|c|c|}
\hline \multirow{2}{*}{$\mathrm{N}_{0}$} & \multirow{2}{*}{$\begin{array}{c}\text { Bulan } \\
\text { Periode }\end{array}$} & \multirow{2}{*}{ Satuan } & \multicolumn{2}{|c|}{ Juli } & \multicolumn{2}{|c|}{ Agustus } & \multicolumn{2}{|c|}{ September } & \multicolumn{2}{|c|}{ 0ktober } & \multicolumn{2}{|c|}{ November } & \multicolumn{2}{|c|}{ Desember } \\
\hline & & & I & II & $\mathrm{I}$ & II & $\mathrm{I}$ & II & $\mathrm{I}$ & II & $\mathrm{I}$ & II & $\mathrm{I}$ & II \\
\hline 20 & Efsiensini rigasi( Eff) & $\%$ & 0,650 & 0,650 & 0,650 & 0,650 & 0,650 & 0,650 & 0,650 & 0,650 & 0,650 & 0,650 & 0,650 & 0,650 \\
\hline 21 & Kebutuhan Air diSal Intake (DR) & Vdtha & $-0,109$ & 1,341 & 1,328 & 0,705 & 1,561 & 2,378 & 1,111 & 0,092 & 0,064 & $-0,151$ & 0,741 & 0,809 \\
\hline 22 & Debit Andalan Q80 & Vdtha & 6,797 & 6,171 & 6,446 & 6,178 & 6,483 & 9,391 & 10,102 & 6,353 & 6,032 & 10,013 & 6,245 & 3,930 \\
\hline 23 & Neraca Air & Vdtha & 6,906 & 4,830 & 4,719 & 5,473 & 4,922 & 7,013 & 8,991 & 6,260 & 5,969 & 10,164 & 5,504 & 3,121 \\
\hline 24 & Terpenulititidak & terpenuh & terpenuhi & terpenul & terpenuh & terpent & erpenu & terpent & terpenulh & terpenul & terpenul & terpenul & terpendil & terpenuli \\
\hline
\end{tabular}




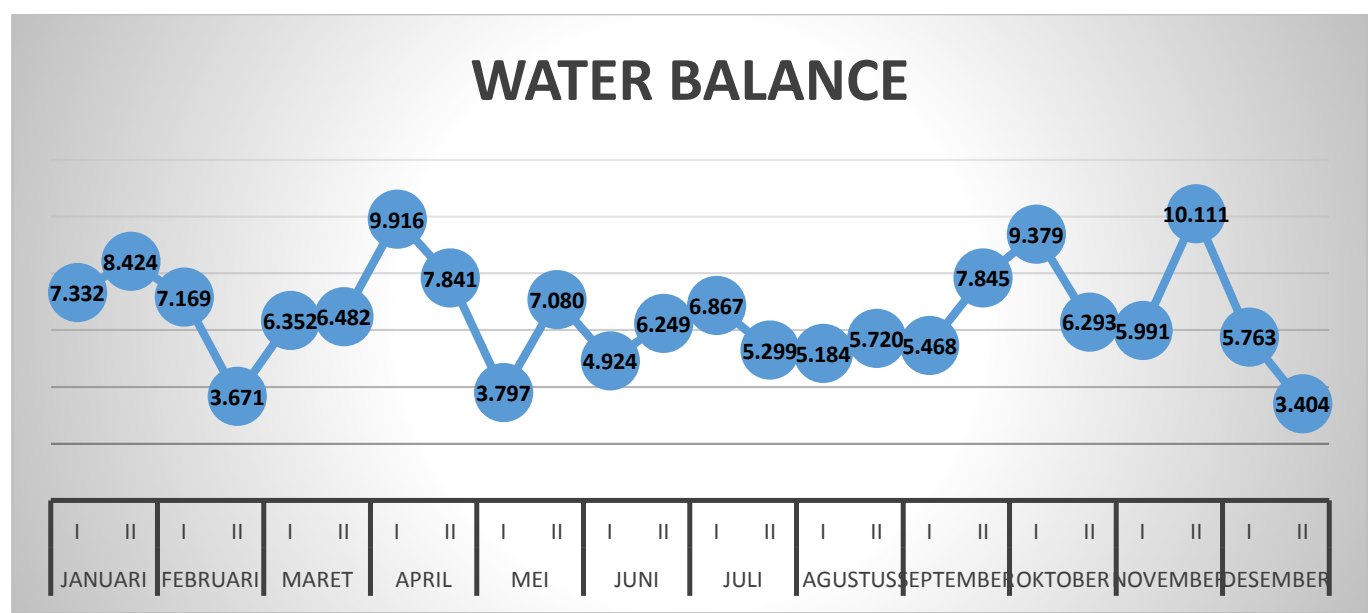

\section{CONCLUSION}

In this study, 12 alternatives were used for the simulation of cropping patterns, out of the 12 alternatives the 7th alternative was chosen as the best and most efficient cropping pattern, with the following considerations

From the conclusion of the Mainstay Debit, the PADI-PADI-PALAWIJA Planting Pattern is adopted, the PADI crop starts planting in February-May, in June the Planting Process (BERO) is not carried out, after that the PADI Planting is carried out again from July - October, on November - January security PALAWIJA.

PADI crops were taken in February and July because in that month the availability of water in the Irrigation District of Solok was very large, as evidenced by the results of the Mainstay Debit, and the PADI plants also needed a lot of water for land preparation (LP), so that the water could be used maximally

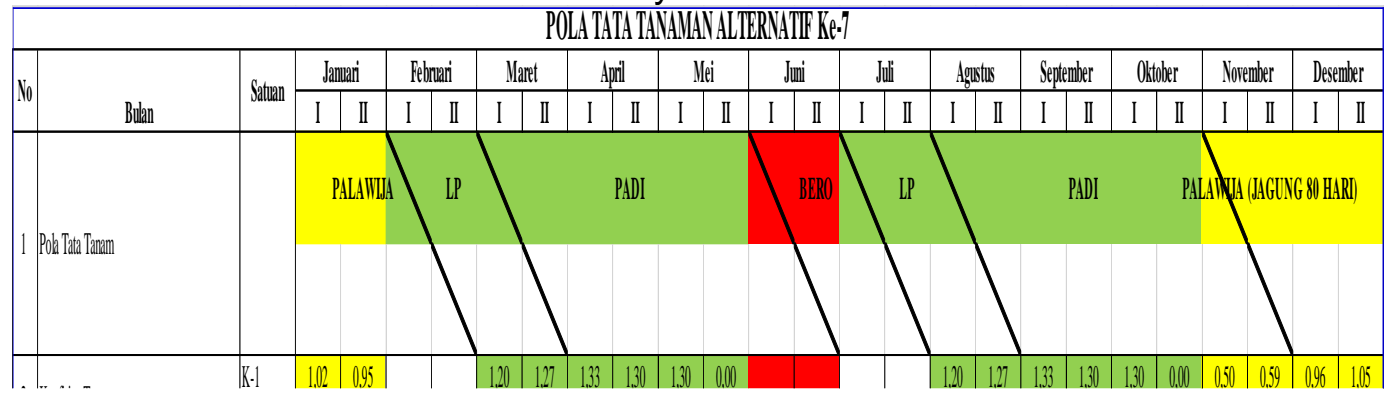

\section{REFERENCES}

A. Priyonugroho, "Journal Of Civil And Environmental Engineering 2.3," Analisis Kebutuhan Air Irigasi (Studi Kasus Pada Daerah Irigasi Sungai Air Keban Daerah Kabupaten Empat Lawang), 2014.

Badan Pusat Statistik Kabupaten Solok, 2010.

"RPIJM - Rencana Terpadu dan Program Infrastruktur Jangka Menengah Kabupaten Solok," 2014.

M. Udiana, “Jurnal Teknik Sipil 1.3," Kajian Sistem Irigasi Sprinkler di Desa Oesao Kabupaten Kupang, 2012.

Standar Perencanaan Irigasi, Kriteria Perencanaan Bagian Jaringan Irigasi, KP-01., 2010.

D. H. U. Ningsih, "Dinamik 17.2," Metode thiessen polygon untuk ramalan sebaran curah hujan periode tertentu pada wilayah yang tidak memiliki data curah hujan, 2012. 
A. KAELISMA, "Kurva S Jurnal Mahasiswa," Analisa Jaringan Irigasi pada Daerah Irigasi (DI) Tepian Buah Kabupaten Berau Kalimantan timur, 2018.

P. D. H. Ardana, Analisis Kebutuhan Air Irigasi Di Daerah Irigasi (Di.) Tengkulak Mawang Pada Daerah Aliran Sungai (Das.) Petanu Di Kabupaten Gianyar, 2019. 